UIV norden

\title{
The Nordic Swan and companies
}

- Is it worthwhile to acquire the Swan Label?

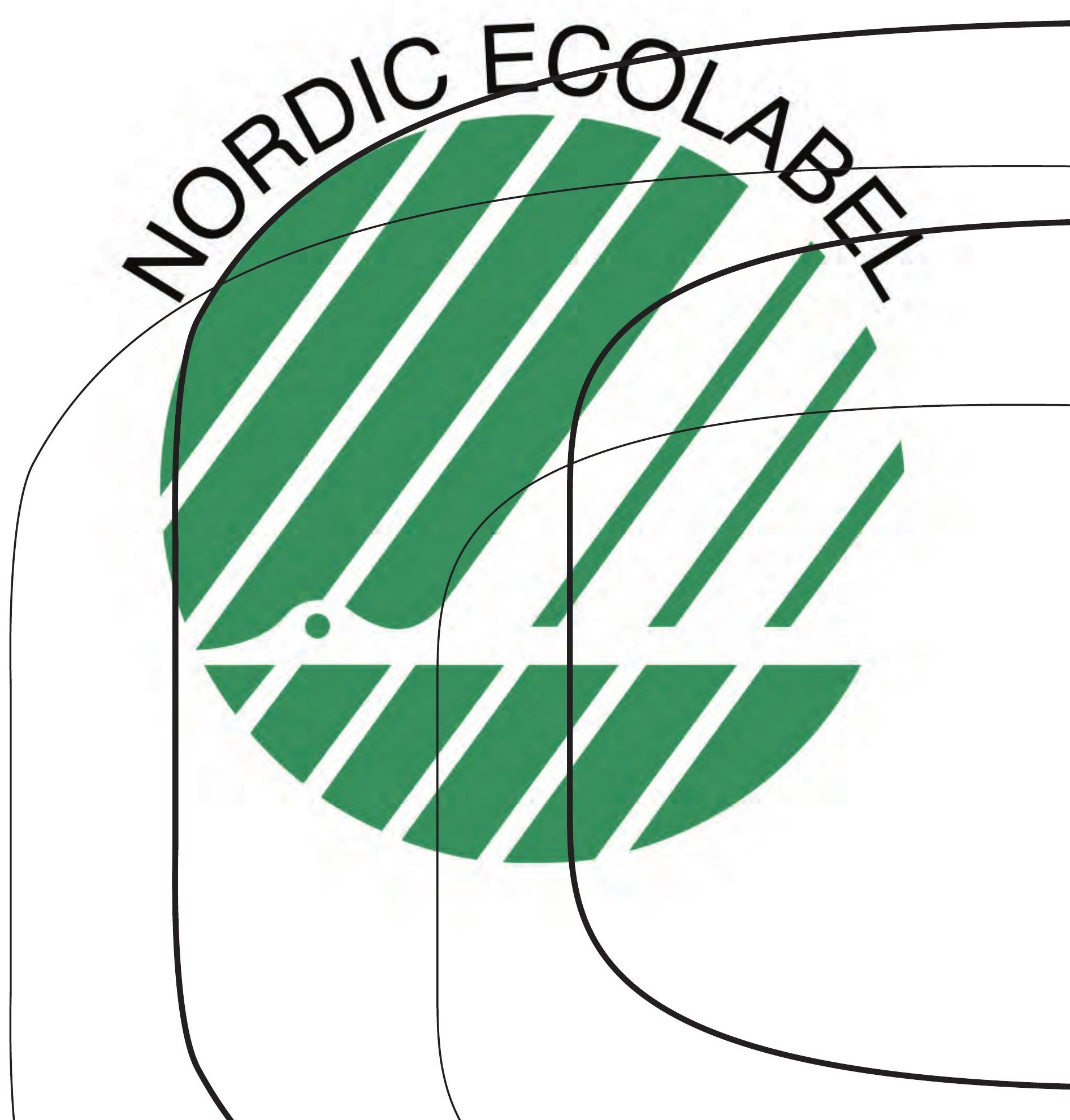



4 norden 



\section{The Nordic Swan and companies}

- Is it worthwhile to acquire the Swan Label?

Ulrik Boe Kjeldsen, Morten Wied, Peter Lange, Maja Tofteng and Kasper Lindgaard 
The Nordic Swan and companies

- Is it worthwhile to acquire the Swan Label?

Ulrik Boe Kjeldsen, Morten Wied, Peter Lange, Maja Tofteng and Kasper Lindgaard

ISBN 978-92-893-2758-9

ISBN 978-92-893-2759-6 (EPUB)

http://dx.doi.org/10.6027/TN2014-523

TemaNord 2014:523

ISSN 0908-6692

(c) Nordic Council of Ministers 2014

Layout: Hanne Lebech

This publication has been published with financial support by the Nordic Council of Ministers. However, the contents of this publication do not necessarily reflect the views, policies or recommendations of the Nordic Council of Ministers.

www.norden.org/en/publications

\section{Nordic co-operation}

Nordic co-operation is one of the world's most extensive forms of regional collaboration, involving Denmark, Finland, Iceland, Norway, Sweden, and the Faroe Islands, Greenland, and Åland.

Nordic co-operation has firm traditions in politics, the economy, and culture. It plays an important role in European and international collaboration, and aims at creating a strong Nordic community in a strong Europe.

Nordic co-operation seeks to safeguard Nordic and regional interests and principles in the global community. Common Nordic values help the region solidify its position as one of the world's most innovative and competitive.

\section{Nordic Council of Ministers}

Ved Stranden 18

DK-1061 Copenhagen K

Phone $(+45) 33960200$

\section{www.norden.org}




\section{Content}

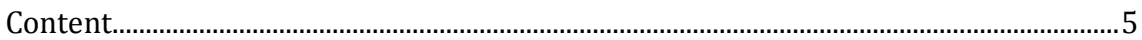

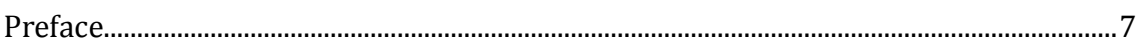

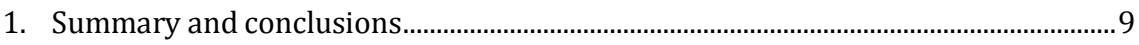

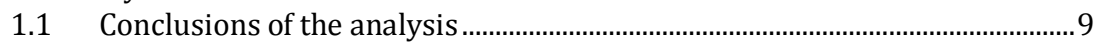

2. About the Swan Label................................................................................................. 17

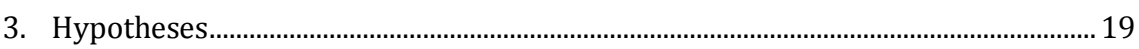

3.1 Limitations and considerations........................................................................ 22

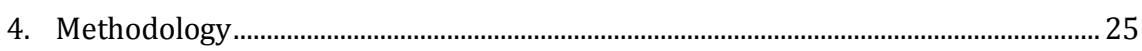

5. Motivation for acquiring the Swan Label ..................................................................... 27

5.1 Sustaining or obtaining a green profile ……................................................... 27

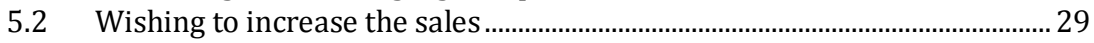

Case: Vester Kopi - Denmark ......................................................................................... 30

5.3 The market pressure raises motivation for the Swan Label.......................... 31

Case: Ballograf - Sweden ............................................................................................ 32

5.4 Wanting to be at the forefront of environmental regulation .......................... 33

5.5 Wishing to streamline the production with the Swan Label........................... 33

6. The implementation of the Swan Label .................................................................... 35

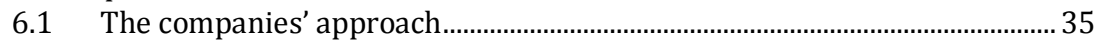

6.2 Success requires motivation and commitment ................................................. 36

6.3 Costs of the Swan Label................................................................................... 37

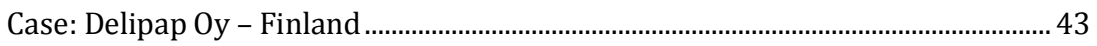

7. The impact and benefits of the Swan Label................................................................ 47

7.1 The Swan Label's impact on the value chain .................................................. 48

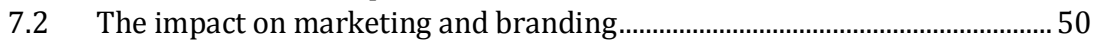

7.3 The impact on HR and recruitment................................................................ 54

7.4 The impact on the use of resources .............................................................. 57

Case: Holmenkollen Park Hotel Rica Oslo - Norway .................................................... 61

7.5 The impact on innovation and development.................................................... 63

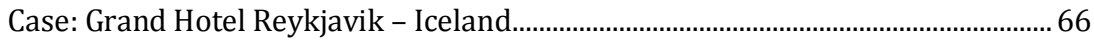

7.6 Impact of the Swan Label - an overview.......................................................... 68

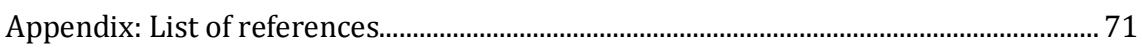

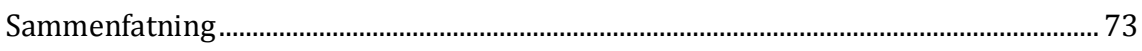

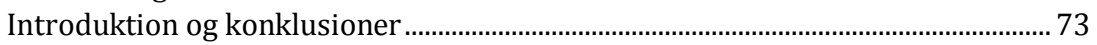

Analysens konklusioner ............................................................................................ 73 


\section{List of figures and tables}

Figure 1: The hypotheses - an illustrative example.......................................................... 19

Figure 2: Swan labelled companies put pressure on subcontractors to be more environmentally friendly

Figure 3: Swan labelled companies put pressure on subcontractors to acquire the Swan Label

Figure 4: Consumers demanding Swan labelled products/services puts pressure on companies to become Swan labelled.

Figure 5: The Swan Label as an integrated part of the branding ................................. 52

Figure 6: The Swan Label as an internal marketing tool................................................ 56

Table 1: An overview of the hypotheses of the analysis.............................................. 21

Table 2: An overview of the expected costs incurred by the Swan Label................. 22

Table 3: Application fees, renewal fees and expansion fees.......................................... 38

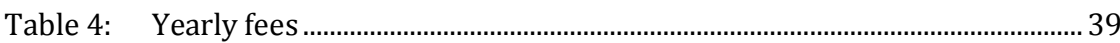

Table 5: An overview of the expected costs incurred by the Swan Label................. 40

Table 6: Hypothesis regarding the Swan Label's impact on marketing and

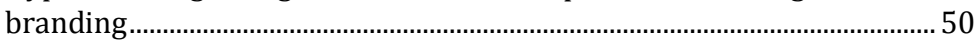

Table 7: Hypothesis regarding the Swan Label's impact on HR and recruitment................................................................................................................. 55

Table 8: Hypothesis regarding the Swan Label's impact on resource effi-

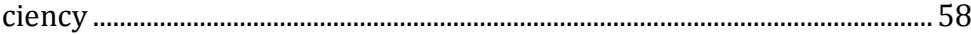

Table 9: Hypothesis regarding the Swan Label's impact on innovation and development

Table 10: Overview of the impact of the Swan Label experienced by the

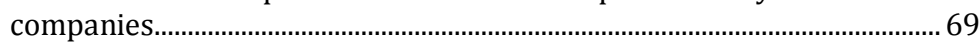

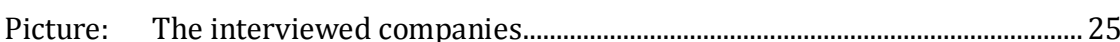




\section{Preface}

This analysis is the product of the project "Svanen 2015 - Beräkningar av Svanen-märkningens värde för företag." The project is commissioned by the Swan group under the Working Group for Sustainable Consumption and Production group (HKP gruppen) of the Nordic Council of Ministers.

The project's purpose is to provide new knowledge on how the Swan Label has an impact on the companies acquiring it - what are the benefits and costs of the Swan Label. The project aims at doing this by performing company visits to 16 companies from the five Nordic countries representing different company sizes and sectors.

The analysis is conducted by DAMVAD (see www.damvad.com) with expert assistance from Åke Thidell, Lund University.

The Nordic Working Group for Environment and Economy followed the project and gave content-wise input.

The report is structured as follows:

Chapter 1 gives a short introduction to the analysis and presents the main findings and conclusions. Chapter 2 shortly presents the Swan Label while chapter 3 outlines the hypotheses for the analysis. The methodology is presented in chapter 4 while chapter 5 looks closer at the motivational factors influencing a Nordic company to acquire the Swan Label. Chapter 6 describes how companies implement the Swan Label, the changes it leads to as well as the costs it incurs, while chapter 7 presents the benefits companies achieve by having the Swan Label. A summary in Danish is available at the end of the report along with the appendix.

Reykjavik, February 2014

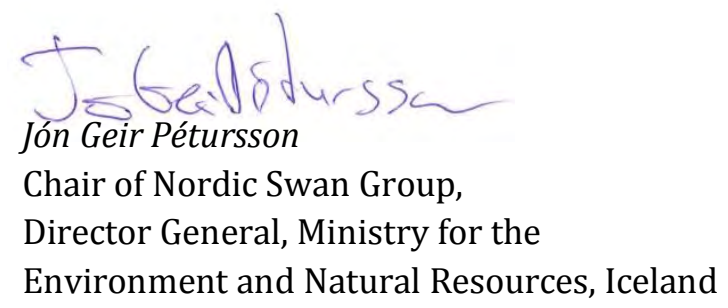





\section{Summary and conclusions}

The Nordic Council of Ministers has asked DAMVAD (see damvad.com) to perform an analysis of the impact of the Nordic Ecolabel - the Swan Label. The purpose of the analysis is to study the implications it can have for a company to acquire the Swan License, regardless of whether the company has a single product licensed with the Swan Label or the entire company is Swan labelled.

The analysis, however, takes a broad focus and investigates the following three themes:

- The motivation for companies to acquire the Swan Label.

- The implementation of the Swan Label.

- The impact of acquiring the Swan Label.

The central part of the analysis is the identification of the impact which the Swan Label can lead to. However, in order to understand and reflect on the impact it is important to understand the motivational factors for why companies acquire the Swan Label and how they implement the label.

\subsection{Conclusions of the analysis}

The analysis performed among 16 companies in the five Nordic countries has made it possible to identify a number of concrete examples of costs and benefits which the Swan Label has for companies in different parts of the value chain.

All companies interviewed experienced an impact from the Swan Label but the types of impact and the magnitude of these vary to a large extent. The selection of the companies for the analysis has been done with considerations towards covering all of the five Nordic countries, several and different sectors (such as hotels, printing companies, production companies and furniture producers) as well as different sizes of the companies.

The conclusions of the analysis covering companies' motivational factors, how they implement the Swan Label and the impacts are described in the following. A separation between these three themes has 
been made in the analysis and the conclusions for each of the themes are presented below.

\subsubsection{Sustaining or obtaining a green profile and increasing the sales are the primary motivational factors for acquiring the Swan Label}

The analysis has identified a number of motivational factors for acquiring the Swan Label. However, the two dominating factors - mentioned by all companies - are that companies wish to sustain or obtain a green company profile and that they wish to increase the sales.

The first group of companies is either companies having had a green profile for years wishing to further strengthen this, or companies wishing to obtain a green(er) profile using the Swan Label as a driver for this. These companies consider the Swan Label to be a "stamp of approval" of their environmental efforts.

All companies interviewed, furthermore, have a wish to increase their sales through the implementation of the Swan Label. They implement the Swan Label relying on the brand value of the label to help them increase their sales targeted at either existing customers or new customers. Many of the companies have seen an increasing interest in buying green products or services among customers, being it consumers, other companies or the public sector. As a response to this, the companies implement the Swan Label. An example of this is Finnish hygiene product producer Delipap Oy which was motivated directly through one of the company's larger customers - a private label company wanting to have the Swan Label on its products.

Moreover, other motivational factors play a role when companies choose to implement the Swan Label. For some companies there is a market pressure for having the Swan Label. In some sectors the Swan Label has become a market standard making it impossible to sell products or services without having the Swan Label. Other companies experience a pressure from the consumers or from business partners.

For other companies the motivation for implementing the Swan Label is an ambition to be at the forefront of coming environmental regulation or to streamline the production using the Swan Label as a driver. 


\subsubsection{The Swan Label strengthens the environmental profile and can be a prerequisite for sales}

The Swan label has positive impacts on sales and marketing for the companies because it makes it easy to communicate and market the environmental work that the company is doing. One company describes the Swan Label as [a] "signal to the consumer that we put action behind our words." Several companies describe how the Swan Label has improved their environmental profile and given them better exposure towards their customers. The Swan Label improves the marketing possibilities and signals quality and responsibility.

In some markets the Swan Label has become a prerequisite for selling products or services - i.e. a market standard - and the companies underline that they would not be active on the market without the Swan Label. One example of this is DUNI, a Swedish producer of napkins and candles. There is a market demand from the hotel and restaurant markets in which they operate for the products to be Swan licensed - having the Swan Label has become a market standard and a prerequisite for selling.

However, the interviewed companies also explain how the Swan Label is "part of the package" which the companies sell and one of several selling points alongside prices, quality, image, etc.

\subsubsection{The Swan Label improves work well-being and makes employees proud}

For some of the interviewed companies the Swan Label has had a positive impact on work well-being. This happens when companies, due to the Swan Label criteria, are "forced" to change chemicals or other substances from their products. This often lowers the risk of work accidents and can make the production more comfortable to work in when e.g. strong odours are removed. Undri, and Icelandic soap producer, removed a chemical from one of its products following the Swan licensing process. This led to a better work environment as the production area no longer has the odour of the previously used chemical.

The Swan Label's impact on recruitment is less clear. The companies argue that the Swan Label is a relevant factor when choosing jobs (in particular when working in industries where the physical work well-being is important) but other factors, such as salary, location, activity, management, job security, etc., play a more important role. However, most of the companies interviewed argue that it is their experience that the overall environmental profile of the company is important for many employees and the Swan Label plays an important role for most companies in this context. Thus, when 
it comes to recruiting as well as retaining employees many companies interviewed find that having the Swan Label and being environmentally responsible makes employees proud of their workplace.

\subsubsection{The Swan Label has a significant impact on resource efficiency}

Many of the interviewed companies describe that the Swan registration process has had impacts on the acquisition and use of resources. However, the magnitude and type of resources differ. In general, a separation can be made between the companies which have licensed their entire service or production facility (or licensed several products) and companies having only one or a few products Swan licensed.

Companies from the first group have to meet strict requirements with regard to energy, water and waste, and experience significant changes due to the focus on resources which the Swan Label gives them. Examples of impact for such companies are reductions in yearly waste of 14 per cent and savings of EUR 10,000 on water usage per year.

Companies with only Swan labelled products (and not a service or the entire company) are to a lesser degree able to measure the impact on resources after the introduction of the label. However, also among these companies reductions on resources can be seen. This happens when companies producing products which contain chemicals not allowed according to the Swan criteria are forced to replace these with more environmentally friendly alternatives. Some companies find that they can leave out the chemicals from their products without replacing them, resulting in a cost reduction for the production of the product. Other companies must replace the chemicals with other substances, which in some instances lead to an increase in costs for producing the product while in other cases it leads to cost reductions.

Other examples of savings on resources are reductions in chemical use for a printing company from 20,000 litres per year to 13,000 litres and a hotel which no longer uses chlorine when washing towels and linens - saving 1.5 tonnes of chlorine per year. 


\subsubsection{The Swan Label forces new developments upon the companies}

Companies applying the Swan Label are often "forced" to develop on the product in order to make it environmentally friendly. Many companies have to change the input materials for their products to be able to have them accepted under the Swan Label. This e.g. happens when a company has to substitute a chemical in a certain product or change a specific material from non-degradable to degradable. These companies develop their products as a reaction to the Swan criteria.

Service companies experience the Swan Label's impact on innovation in different ways. For hotels the impact of the Swan Label can mainly be seen in the reduction of resources and to a lesser degree in newer developments. However, some argue that they use the work undertaken as a part of the Swan to offer green or eco conferences, or increase the amount of organic or local food in their restaurants. Printing companies are largely affected by technological changes in their industry. The change towards digital printing makes the printing industry more environmentally friendly and the Swan Label cannot be credited for this development. However, having the Swan Label makes the companies able to offer new services - e.g. printing on "green" paper or offering Swan labelled brochures, posters etc.

\subsubsection{The Swan Label leads to changes in production costs}

The companies implementing the Swan Label all have to pay a number of fees to be able to bear the label. These fees are the direct costs of implementing the Swan Label and consist of an application fee, a renewal fee and a yearly fee based on the sales of the Swan labelled products or services.

However, the companies implementing the Swan Label also experience a number of indirect costs. Most prominent are the changes in production costs following from the Swan Label. The companies experience these when the Swan Label has criteria which "force" them to change input material in the production or invest in the machinery or other equipment. Often, the companies have to change input materials to other alternatives which are more environmentally friendly but also costlier. Furthermore, several companies experience that they have fewer suppliers to choose from when they have to purchase environmentally friendlier materials. It should be noted, however, that some companies experience that the new environmentally friendlier input materials are cheaper to purchase or that they can simply stop using some input materials, saving the costs on these. An example of this is Grand Hotel Rey- 
kjavik in Iceland which changed a number of processes throughout the hotel and had to exchange some products for others while other products and services could be dropped without exchanges. In some areas the hotel now has fewer suppliers to choose from resulting in fewer choices and in some occasions higher costs.

Other indirect costs stemming from the Swan Label are the time used on the application procedure for the Swan Label, the price of assistance from consultants and the education and training of employees. The interviewed companies in particular highlight the time used on the application procedure as an indirect cost of the implementation of the Swan Label. The time is used on increased dialogue with subcontractors and suppliers as well as collection of information about products, input materials or the usage of resources.

\subsubsection{The impact of the Swan Label differs across companies and markets}

The analysis performed shows how the impact of the Swan Label differs to a very large extent across the size of the companies. Impacts, especially related to costs, are often larger for a large company with many employees. Moreover, the impact differs depending on how professionally run the company is and depending on their existing environmental awareness. Some of the companies interviewed have had an environmental awareness for years in advance of acquiring the Swan Label and acquire the Swan Label mainly as a stamp of approval. Such companies have already taken a number of steps to become more environmentally friendly and the Swan Label does not lead to significant changes here.

Similarly, the impact differs across the sectors in which they operate and the maturity of these when it comes to the Swan Label (is the Swan Label a standard on the market or something new?). Thus, some companies operate in markets where the Swan Label is already a standard, meaning that the competitive advantage of acquiring the Swan Label is smaller than for first-mover companies in markets where the Swan Label is not yet a prerequisite for selling goods or services. 


\subsubsection{The impact of the Swan Label is larger for service companies than for production companies}

Based on the interviews conducted it is an observation that the changes stemming from the Swan Label are significantly larger for the service companies than the production companies. This is a result of the fact that for service companies the entire company is being Swan labelled while production companies often Swan Label some of their products.

For service companies this means that they have to go through many of the company's routines, processes as well as they have to have a thorough focus on their usage of resources. A production company Swan labelling one or more products "only" has to document materials and input to these products. The analysis shows that there are more "lowhanging fruits" to pick for the service companies. An example of such a service company is Holmenkollen Hotel RICA in Oslo. During the licensing procedure the hotel has changed routines and procedures throughout the hotel and e.g. changed all light bulbs, installed water saving equipment and changed its waste handling.

Furthermore, this difference in impact could come from a change of attitude in service companies towards being more environmentally friendly, whereas this trend has been evident among many production companies for years. Finally, the incentive structure plays an important role. While service companies can see a direct and immediate impact on their costs, production companies might have a harder time justifying why they should change an input material for another at a higher price in order to obtain a better image among the clients.

\subsubsection{Successful implementation of the Swan Label takes commitment from employees and management}

For companies to be successful in implementing the Swan Label it is a necessity to have commitment from the employees as well as the management of the company. The management has an important role in communicating the advantages of the Swan Label to all levels of the company and to all employees involved. Change management is an important concept in this connection. The employees are important to involve in the implementation process as the changes to routines and processes directly affect their daily tasks. Some companies experience frustration and negative reactions among the employees when these changes occur. To avoid such reactions involvement of the staff is a key to success. 


\subsubsection{Exact information on costs and benefits are limited}

The interviews conducted during the study have shown that it is difficult to obtain precise estimates as to what the precise value of the Swan Label is for the companies. There are a number of reasons for this, among which are:

- Companies do not track the actual costs and benefits of the Swan Label.

- Some products and services are certified prior to being brought on the market, meaning that it is not possible to measure "before and after" effects.

- The impact differs across company size and sector making it difficult to provide an exact estimate.

These points underline the challenge in estimating and quantifying an exact impact of the Swan Label which can be said to be true for all companies. However, based on the interviews performed the report gives an idea of the costs and benefits which can occur from the implementation of the Swan Label. The general opinion of the companies interviewed is very positive towards the Swan Label and as mentioned it becomes an integrated and important part of these companies.

For future analyses there are in particular two possibilities for acquiring more knowledge of the impact of the Swan Label. First of all, the service companies report their resource usage of e.g. water and electricity to the Swan Label secretariats. It would be interesting to look further into this data and analyse the changes in resource usage following from the requirements of the Swan Label.

Secondly, it would be interesting to perform a statistical impact assessment of the performance of Swan labelled companies in the Nordic companies measured in e.g. turnover, exports, employment and productivity. The level of detail in the data of the statistical bureaus allows for comparing Swan labelled companies with a control group of other companies similar to the Swan labelled companies, but who do not have Swan labelled products or services. 


\section{About the Swan Label}

The Nordic Ecolabel (also known as and onwards mentioned as the Swan Label) is the official ecolabel of the Nordic countries, i.e. Denmark, Finland, Iceland, Norway and Sweden. The Swan Label is an initiative by the Nordic Council of Ministers and was established in 1989. The purpose of the Swan Label is to provide an environmental labelling scheme that will contribute to a sustainable consumption as well as providing a practical tool for consumers to be able to choose environmentally-sound products. ${ }^{1}$ The participating companies receive a license and are permitted to sell the products and services with the Swan Label signalling that these are environmentally friendly and that they have fulfilled stringent environmental and climate criteria.

\subsubsection{Fees}

The Swan Label is voluntary for companies to participate in and acquire. However, the companies have to pay fees to get products or services approved and yearly fees based on the sales of those products or services. The fees differ across the Nordic countries but are specified later in the report. ${ }^{2}$

\subsubsection{License criteria}

To be able to obtain a Swan Label a company's product or service must live up to the criteria defined for the specific product or service. There are currently 63 criteria set covering more than 200 different groups under which companies can have their products and services approved. An example of a product group is "Hand Dishwashing Detergents" while an example of a service group is "Hotels and youth hostels". The criteria are described in a very detailed manner in documents available online. ${ }^{3}$

\footnotetext{
1 Based on http://www.nordic-ecolabel.org/about/ and http://www.ecolabel.dk/ svanenblomsten/omsvanenblomsten/

2 Based on research done during the work on the report "The coexistence of two Ecolabels - The Nordic Ecolabel and the EU Ecolabel in the Nordic Countries", DAMVAD 2013, forthcoming.

${ }^{3}$ http://www.nordic-ecolabel.org/criteria/product-groups /
} 
A company wanting to carry the Swan Label can apply at the national office in the market where they want to sell Swan labelled products or services. In each of the Nordic countries local national offices have the responsibilities of criteria development, licensing, marketing and audits. The company is awarded the Swan Label through a licensing process where licences are granted to products or services that fulfil the criteria.

The license criteria are developed by experts from the Nordic Ecolabelling organisations. Experts from ministries, environmental organisations, producers, etc. give their opinion and, thus, indirectly participate in the development of criteria. Before The Nordic Ecolabelling Board finalises the criteria, they are sent out for review. To ensure that Swan labelled products/services are as environmentally friendly as possible the criteria are continuously reviewed and revised every 3-5 years. This is done to take into account product development progress and new scientific discoveries as well as new information about environmental impact. Products or services carrying a Nordic Ecolabel licence must apply and fulfil the new criteria requirements. ${ }^{4}$

${ }^{4}$ http://www.nordic-ecolabel.org/criteria/the-criteria-process/ 


\section{Hypotheses}

Prior to the analyses, concrete hypotheses regarding the impact of the Swan Label in a company's value chain have been formulated with a focus on the benefits the Swan Label can lead to and the costs it can incur. These hypotheses have initially been formulated by the Nordic Council of Ministers Swangroup and since then re-worked by DAMVAD and Åke Thidell.

The hypotheses formed a basis for formulating an interview guide which has been used to interview selected companies across the Nordic countries. The interview guide secures that respondents have been asked directly and thoroughly about the costs and benefits of the Swan Label and, if possible, to give a quantification of these.

The hypotheses on potential benefits are illustrated according to a company's value chain below and an example of the impact on a company's marketing is given:

Figure 1: The hypotheses - an illustrative example

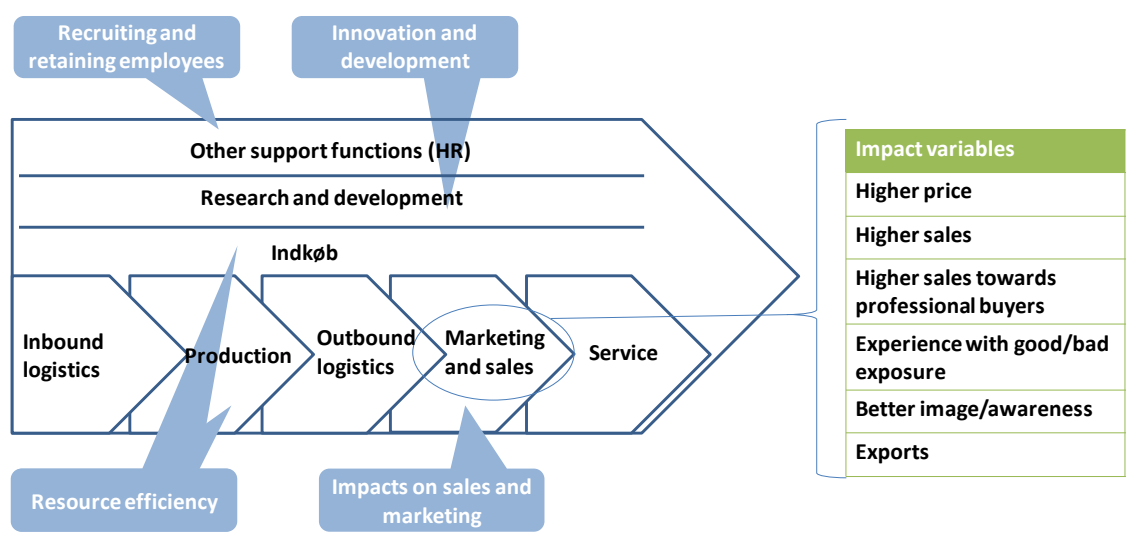

Source: DAMVAD, 2013. 
The four overall hypotheses formulated regarding the Swan Label's benefits for a participating company are:

- The Swan Label has a positive impact on a company's marketing and branding.

- The Swan Label has a positive impact on a company's HR and recruitment.

- The Swan Label has a positive impact on a company's resource efficiency.

- The Swan Label has a positive impact on a company's innovation.

Regarding marketing and branding the hypothesis is that having the Swan Label will give a product or a company a green, trustworthy credibility towards consumers and that environmentally concerned consumers specifically will be searching for and selecting Swan labelled products or companies. Another hypothesis is that the Swan Label strengthens the positioning of a company and its products or services towards professional, public buyers. Finally, it is hypothesised that the Swan Label can have spill-over effects to the company's brand and signal environmental consideration to a higher degree than otherwise.

Regarding HR and recruitment it is prior to the analyses hypothesised that employees are more motivated when working for companies taking environmental and societal responsibility. The Swan Label is expected to have a positive effect on the attractiveness of the company as a workplace. Furthermore, it is expected that the acquisition of the Swan Label can have a positive effect on some companies' work well-being due to reductions in chemicals and similar dangerous substances.

Regarding resource efficiency the Swan Label is expected to lead to a more efficient use of resources, e.g. less water or energy use and reduced waste disposal. Furthermore, the Swan Label is expected to influence companies' production processes and the effectiveness of such processes. Finally, the Swan Label is expected to be able to lead to an optimisation of the value chain with a focus on quality and the environment.

Regarding Innovation and development it is hypothesised that having the Swan Label will lead to investments in product development and optimisation of production processes - in the form of new innovative approaches to such processes. It is also expected, that companies living up to the Swan criteria will gain knowledge on how an environmentally friendly product is produced, thereby improving product development. 
Table 1: An overview of the hypotheses of the analysis

\begin{tabular}{|c|c|c|}
\hline Hypotheses & Causal relationship & Examples of indicators \\
\hline \multicolumn{3}{|c|}{ Impact on marketing and branding } \\
\hline $\begin{array}{l}\text { The Swan Label strengthens } \\
\text { the companies' possibilities } \\
\text { for positioning in their } \\
\text { markets }\end{array}$ & $\begin{array}{l}\text { The Swan Label gives a product/service a "envi- } \\
\text { ronmental trustworthyness" among consumers } \\
\text { Environmentally concerned consumers will } \\
\text { deliberately pick Swan labelled products/services } \\
\text { The Swan Label reduces the risk of bad exposure } \\
\text { The Swan Label strengthens the positioning } \\
\text { towards professional buyers, e.g. the public sector } \\
\text { The Swan Label supports CSR-activities } \\
\text { The Swan Label can result in spill-over effects } \\
\text { towards the brand of the company, as well as the } \\
\text { company's other products/services }\end{array}$ & $\begin{array}{l}\text { Higher prices } \\
\text { Higher sales } \\
\text { Higher sales towards } \\
\text { professional buyers } \\
\text { Experiences with } \\
\text { good/bad exposure } \\
\text { Brand value: better } \\
\text { image, better recognition } \\
\text { Export possibilities }\end{array}$ \\
\hline \multicolumn{3}{|l|}{ HR and recruitment } \\
\hline $\begin{array}{l}\text { The Swan Label improves } \\
\text { companies' ability to } \\
\text { recruit, retain and motivate } \\
\text { employees }\end{array}$ & $\begin{array}{l}\text { Employees are more motivated in companies } \\
\text { taking a social responsibility } \\
\text { The social responsibility strengthens the compa- } \\
\text { ny's attractivenes as a work place } \\
\text { Improved work well-being, e.g. as a result of } \\
\text { handling less dangerous chemicals } \\
\text { Possibilities for courses and other types of } \\
\text { qualification for the employees }\end{array}$ & $\begin{array}{l}\text { Increased number of } \\
\text { applications } \\
\text { Lower employee turnover } \\
\text { Fewer sick days } \\
\text { Results in work place } \\
\text { assessments are better }\end{array}$ \\
\hline \multicolumn{3}{|l|}{ Resource efficiency } \\
\hline $\begin{array}{l}\text { The Swan Label reduces } \\
\text { companies' production costs }\end{array}$ & $\begin{array}{l}\text { More effective use of resources, e.g. less useage } \\
\text { of water, energy and less waste disposal } \\
\text { Focus on long term benefits of changing or } \\
\text { adjusting the production } \\
\text { Spill-overs from efficiency improvements to- } \\
\text { wards other products than the Swan labelled } \\
\text { Optimisation of the value chain through a focus } \\
\text { on quality and environmental demands } \\
\text { Possibility of lower or higher input costs due to } \\
\text { more expensive raw materials }\end{array}$ & $\begin{array}{l}\text { Reduced garbage } \\
\text { disposal } \\
\text { Reduced usage of elec- } \\
\text { tricity, water, heat, etc. } \\
\text { Efficiency improvements } \\
\text { in the production (fewer } \\
\text { man hours) } \\
\text { Lower costs for purchas- } \\
\text { ing, consistent deliveries, } \\
\text { higher quality of inputs } \\
\text { Lower/higher costs of } \\
\text { input materials }\end{array}$ \\
\hline \multicolumn{3}{|l|}{ Innovation and development } \\
\hline $\begin{array}{l}\text { The Swan Label provides } \\
\text { motivation for product } \\
\text { development and innovation }\end{array}$ & $\begin{array}{l}\text { The changes and developments of the Swan } \\
\text { criteria leads companies to invest more in product } \\
\text { development and optimisations in the production } \\
\text { Companies gain access to new and updated } \\
\text { knowledge on product development via the Swan } \\
\text { labelling process } \\
\text { Companies foresee and reduce costs incurring } \\
\text { from environmental regulation }\end{array}$ & $\begin{array}{l}\text { Product development led } \\
\text { on by the Swan criteria } \\
\text { Changes in subcontrac- } \\
\text { tors } \\
\text { Larger demands towards } \\
\text { existing subcontractors } \\
\text { Has the company been } \\
\text { at the forefront of } \\
\text { environmental regula- } \\
\text { tion - has this resulted in } \\
\text { competitive advantages } \\
\text { such as a stronger } \\
\text { position in the market or } \\
\text { reduced costs? }\end{array}$ \\
\hline
\end{tabular}

Source: DAMVAD, 2013.

Furthermore, and as mentioned above, the analysis looks further into the costs a company incurs by acquiring the Swan Label and will identify and quantify these to the extent possible. In the following table an overview of expected costs for participating companies can be seen. Here, the 
most interesting costs to examine are the indirect costs, as the direct costs are to be paid by all companies acquiring the Swan Label.

\begin{tabular}{ll} 
Table 2: An overview of the expected costs incurred by the Swan Label \\
\hline Type of cost & Examples of indicators \\
\hline Direct costs & $\begin{array}{l}\text { Application fee } \\
\text { Usage fee } \\
\text { Renewal fee } \\
\text { Fee for control visits } \\
\text { Fee for the extension of current license } \\
\text { Indirect costs }\end{array}$ \\
& $\begin{array}{l}\text { Time used on the application procedure } \\
\text { Changes in the production (costs higher or lower as a } \\
\text { result) } \\
\text { Investments in new technology } \\
\text { Assistance from consultants } \\
\text { Lower/higher costs of raw materials and input to the } \\
\text { production } \\
\text { Education or training of employees }\end{array}$ \\
\hline
\end{tabular}

Source: DAMVAD, 2013.

These hypotheses about costs and benefits are tested during the analyses performed with the purpose of investigating whether they can be confirmed and to which degree. Other unforeseen costs and benefits of having the Swan Label uncovered during the analyses are similarly discussed.

\subsection{Limitations and considerations}

The overall purpose of this project has been to identify and, if possible, to quantify the impact of the Swan Label for the license holders - i.e. the costs and benefits of implementing and carrying the Swan Label.

However, the interviews have shown that there are a number of issues to consider. Besides the fact that the impact differs across company size, type and sector as described above, a number of other factors play a role:

- Some companies have their products Swan labelled even before sending them on the market meaning that the impact of the Swan Label on sales is not possible to investigate (there is no before sales to compare with). 
- Furthermore, the time perspective plays an important role.

Companies having implemented the Swan Label many years ago have difficulties in estimating the impacts it has made. Some of these companies also describe how the impact of the Swan Label stagnates over time as other companies acquire the label or apply other environmental initiatives.

- Although not clearly stated by the companies, some concerns towards anonymity and the release of company sensitive information have been sensed during the interviews. Some of the companies are reluctant to give precise information even though they have been promised anonymity regarding concrete information or examples of benefits obtained measured in DKK/EUR.

- Finally, none of the companies interviewed actually track the costs and benefits of having the Swan Label in detail. Naturally though, most companies have an idea of the costs and benefits and some companies have detailed information on parts of the costs or benefits.

These points underline the challenge in estimating and quantifying an exact impact of the Swan Label which can be said to be true for all companies. Such quantification cannot be made. It should, furthermore, be underlined that the analysis is carried out qualitatively based on 16 company interviews.

However, based on the interviews performed this report gives an idea of the costs and benefits which can occur from the implementation of the Swan Label. The report also gives a number of examples of detailed reductions in usage of resources, reduced costs for inputs to products, etc. and their monetary value for the companies. 



\section{norden}

Nordic Council of Ministers

Ved Stranden 18

DK-1061 Copenhagen K

www.norden.org

\section{The Nordic Swan and companies}

The purpose of the analysis is to study the implications it can have for a company to acquire the Swan License. The analysis takes a broad focus and investigates the following three themes:

- The motivation for companies to acquire the Swan Label

- The implementation of the Swan Label

- The impact of acquiring the Swan Label

The project aims at doing this by performing company visits to 16 companies from the five Nordic countries representing different company sizes and sectors.

The project is commissioned by the Swan group under the Working Group for Sustainable Consumption and Production (HKP gruppen) of the Nordic Council of Ministers. The analysis is conducted by DAMVAD with expert assistance from Åke Thidell, Lund University.

TemaNord 2014:523

ISBN 978-92-893-2758-9

ISBN978-92-893-2759-6 (EPUB)

ISSN 0908-6692

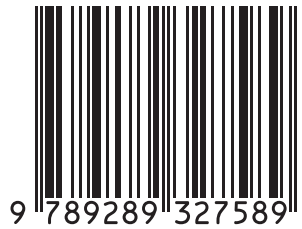




\section{Methodology}

The analysis has been conducted with a strong focus on company specific costs and benefits resulting from the acquisition of the Swan Label but covering companies' motivation for the acquisition and their experiences with implementation as well.

16 case studies have been conducted among companies across the five Nordic countries having either products, services or the company itself Swan licensed. The selection of the companies for the analysis have been done with considerations towards covering all countries, several and different sectors as well as sizes of the companies. Finally, considerations towards time of implementation of the Swan Label as well as whether the companies hold other environmental certificates, labels or standards have been made.

Picture of The interviewed companies

\begin{tabular}{|c|c|c|c|c|c|}
\hline & Denmark & Finland & Iceland & Norway & Sweden \\
\hline Consumer goods & & EDelipa & حئني & bor & \\
\hline $\begin{array}{l}\text { Construction } \\
\text { products }\end{array}$ & $=D$ DYRUP & & & QJOTUN & \\
\hline Furniture & rumas & & & SEN & norrgavel \\
\hline Hotels & & & $\begin{array}{l}\text { कु) } \\
\text { HOTEL } \\
\text { REYKJAVI }\end{array}$ & ROA & \\
\hline $\begin{array}{l}\text { Printing } \\
\text { companies }\end{array}$ & Vester Kopi & & Îno & & \\
\hline Office supplies & & $\begin{array}{l}\text { Wive } \\
\text { storoenso } \\
\text { sile }\end{array}$ & & & (1) BALLOGRAF: \\
\hline
\end{tabular}


The selected companies have been interviewed during on-site visits. Prior to the interviews the companies have been prepared as to which themes and types of questions would be asked. The interviews followed a well-structured interview guide divided into the themes also used in this report - the motivation for acquiring the Swan Label, the implementation of the label and the impact it has on the companies at various places in the value chain. In all companies an effort was made to interview several representatives from different departments or areas of the companies to be able to examine the impact which the Swan Label has on different parts of the value chain.

The methodology chosen for the analysis is based on the ISO methodology for identifying the benefits of standards. The concept is a sound, internationally known and well-tested approach to identify the impact of standards through a company's value chain. ${ }^{5}$

The methodology identifies indicators for separate parts of a company's value chain and allows for the formulation and testing of hypotheses regarding the effects of different types of standards at the company level. Because of this specialised focus on a company's value chain the ISO methodology has been chosen to analyse the impact of the Swan Label for companies carrying it. 


\section{Motivation for acquiring the Swan Label}

This chapter looks closer at Nordic companies' motivational factors for acquiring the Swan Label for the products, services or the company itself. In the following two chapters the implementation of the Swan Label and the costs incurred (chapter 6 ) as well as the impact stemming from the Swan Label (chapter 7) will be presented.

The motivational factors are important to look closer at as a starting point for the analysis. Deeper knowledge of the motivational factors will contribute to a better understanding of the companies' implementation of the Swan Label, and the barriers and challenges they face, as well as the impact the companies manage to achieve from the Swan Label.

The results from the case interviews point towards two overall motivational factors for all companies: 1 . obtaining or sustaining a green profile and, 2. increasing sales. These two factors are closely related and most often a company wishes to have a green profile so that it can increase the sales. Besides this, a number of other factors play a role given different and varying circumstances. The source for the motivation, however, will often come from top-management using the Swan Label as part of a strategical focus on being green.

\subsection{Sustaining or obtaining a green profile}

As mentioned above one of the main reasons and motivational factors for acquiring the Swan Label is a focus on having a green profile. This is true both for companies already having a green profile as well as for companies wishing to obtain a green profile. The Swan Label acts as a communication tool for all of the companies.

The first group of companies are typically companies that already have had a green profile for a number of years but want to use the label to further strengthen the awareness of this among their customers as well as the general public and authorities. These companies have a focus on the environmental impacts of their activities and were already before the Swan Label attempting to lower their waste disposal, decrease the 
use of energy, reduce the amounts of chemicals used in the production etc. The Swan Label serves as a stamp of approval of their environmental efforts and achievements and is a simple and clear way of sending a signal to customers. The Finnish company Edita is a good example of this.

\section{Communicating responsibility}

Edita, a Finnish printing company, has been Swan labelled since 1993 and had an environmental profile for years. The company has as a goal to be leading in environmental awareness in its business segment and continually aims to reduce its environmental impact. The company saw the Swan Label as a good opportunity to communicate environmental responsibility to its clients.

The second group of companies wish to obtain a green profile and seek to use the Swan Label as an initiative to become greener. These companies acquire the Swan Label and use it as a driver for changing processes, products or services towards being more environmentally friendly. They also find the Swan Label to be a good and simple way of demonstrating the positive characteristics of their products and services. However, even though the environmental signal following from the Swan Label is important, some of the more experienced companies having certified several products say the decision to certify a product is part of the early investment decision alongside considerations regarding costs, pricing, input factors, marketing, etc. An example of this can be seen in the box below.

\section{Part of the business case evaluation}

Lilleborg, a Norwegian producer of domestic goods such as laundry and cleaning products, has more than 100 Swan labelled products. When they develop new products they will already at the research stage consider if the product could meet the Swan criteria (if there are any for the given product). However, even if meeting the criteria is desirable, most importantly, the product must make a good business case, meaning it must be effective and profitable. 


\subsection{Wishing to increase the sales}

The second important reason companies have for getting the Swan Label is that they expect to increase their sales. The interviewed companies underline how they acquire the Swan Label with the purpose of signalling that they or their products and services are green and hope that this will lead to increased sales. In short, they rely on the brand that the Swan Label has and expect this to create awareness and interest in their company, products or services among their customers. Several companies emphasise that the Swan Label is very well known and recognised in the Nordic countries. Vester Kopi in Denmark is an example of a company using the Swan Label to obtain and sustain a green profile and as a way of increasing the sales (see case description). 


\section{Case: Vester Kopi - Denmark}

\section{Motivation}

Vester Kopi got Swan licensed in 2007 as a result of several motivational factors. First of all, the company could see an increasing demand from public clients in tenders for proofs of the environmental impact of the company. Vester Kopi already had an environmental policy, but needed a "stamp of approval". Secondly, the company expected to be able to obtain increased sales by having a green profile. In connection with this Vester Kopi was seeking to gain a competitive advantage towards their competitors by being able to signal their environmentally friendly awareness.

\section{Implementation}

Before Vester Kopi started the implementation of the Swan Label they cooperated with the business organization of the printing industry in Denmark and estimated the costs and time span needed for the implementation. It was also discussed whether to go for the Swan Label or the EU Ecolabel but the company decided to implement the Swan Label as they felt it was positioned stronger among the consumers as well as the public clients.

The work on implementing the Swan Label was arranged with the help of the business association and among other things it involved the collection of a significant amount of data on e.g. the printing machines and the usage of paper, chemicals, etc.

\section{Effects}

Having the Swan Label has made a number of impacts on the company. First of all, Vester Kopi had to change some of the materials they were using because it was not as environmentally friendly as demanded. Some of these were less expensive for the company to work with while others were more costly. Also, the paper the company was using was changed and as a result they saved 3-5 pct. of their costs of paper. Secondly, Vester Kopi gradually started changing its printing machinery towards greener and more efficient models. Finally, the company mentions the overview of the costs of the company, including usage of electricity, chemicals, etc., as very valuable.

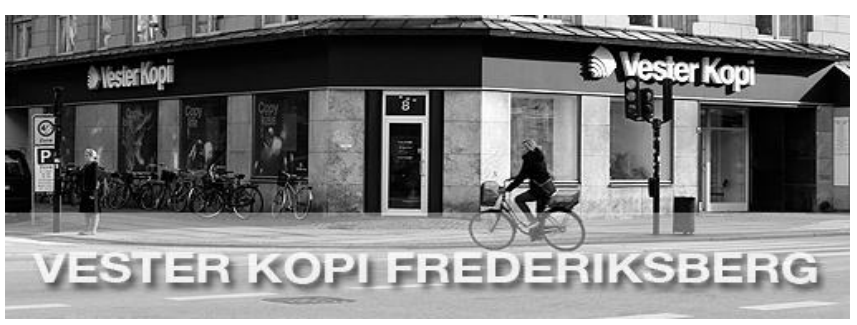

Several of the companies also explain how they have seen an increasing interest in buying green or otherwise environmentally friendly products among their customers. As a means for taking action on this interest the companies have considered different ways to signal their green profile and chosen the Swan Label. Furthermore, some companies also mention that they have sensed or experienced an increased interest from the public sector to purchase environmentally friendly products. As a response to this the companies have chosen to profile themselves with the Swan Label. 


\subsection{The market pressure raises motivation for the Swan Label}

Another motivational factor for several of the companies interviewed is that the Swan Label has become a market standard, subsequently that being environmentally friendly has become the norm. Thus, for many companies there is a market pressure indirectly demanding that the companies acquire the Swan Label (see the case of Ballograf on the following page). In some markets a majority of the products are Swan labelled and the companies' customers (being it consumers or other companies) expect the products to carry the Swan Label.

Furthermore, the Swan Label can affect the value chain and put pressure on some companies to be environmentally friendly and some companies use the Swan Label to put pressure on their subcontractors (see more on this in chapter 7 on impact and an example in the box below).

\footnotetext{
Motivated by the customers

Finnish hygiene product producer Delipap Oy had products Swan labelled in 2006 and again in 2010. The motivation came primarily from one of the company's larger customers - a private label company wanting to have the Swan Label on its products. However, Delipap Oy already had an environmental focus for years and decided that having the Swan Label would be a good way to communicate their environmental responsibility towards their customers and differentiate from competitors.
} 


\section{Case: Ballograf - Sweden}

\section{Motivation}

Since the change of owners in 2005 Ballograf decided to put an increased focus on the environmental impact and awareness of the company.

The company sensed an increased focus on and interest for environmentally friendly products within their business area. This could be seen among their customers providing more and more space in their catalogues for environmentally friendly office supplies. An aim was set: to design and produce a Swan labeled pen. This type of product did not exist on the market at the time.

Implementation

Ballograf has both pens and markers which are Swan labelled. However, the markers became a part of Ballograf's product line as they bought another company while the pens were to be Swan labelled from scratch. The development of the pen was a challenge as the "body" of the pen must be produced mostly of cardboard, each ends of the pen had to be made from recyclable plastic and the ink container also needed to be made from recyclable plastic and contain environmentally friendly ink. This had implications for their subcontractors as they had to develop a new type of ink, and for Ballograf as they among other things had to buy a new mould for casting the pens. In total, the development took 1,5 years.

Impact

The largest impact of the Swan Label for Ballograf has been the strengthened environmental profile of the company and the signal which they can send to their customers. The company believes that the Swan Label has improved the brand of the company and that it is easier to build a brand among customers.

Furthermore, the fact that the pen is the first of its kind to be Swan labelled has created some degree of attention. The company finds that it is easier to get the new pen advertised in catalogues and product magasines as the product is new and a first of its kind.

Regarding environmental responsibility and focus the Swan Label plays an important role. The company has a strategy and philosophy of being green and sees the Swan Label as a natural part of this. The Swan Label has been part of an increased focus on the chemicals used in the production - especially with regards to

ink. It can be used as a tool for the company and strengthens the interest for being environmentally friendly.

Ballograf believes the work they have done on developing the Swan labelled pen will be an advantage and serve as an inspiration to them for the development of future products.
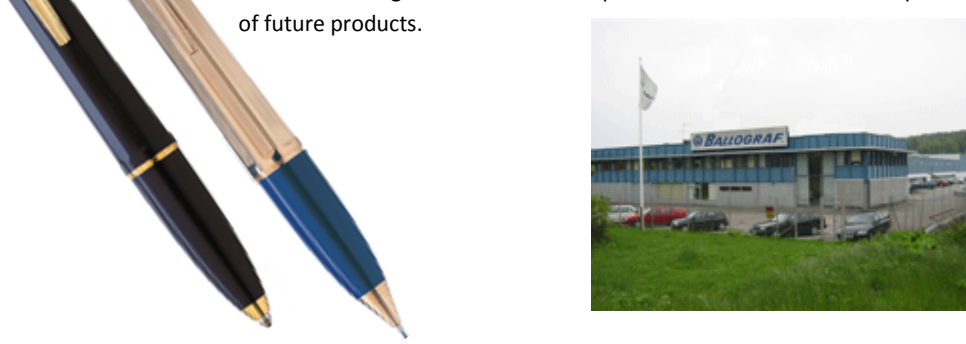


\subsection{Wanting to be at the forefront of environmental regulation}

Some of the interviewed companies describe how they acquire the Swan Label to be able to be at the forefront of upcoming changes to environmental regulation. Companies in this situation are aware of a coming governmental tightening of the environmental footprint of the sector in which they operate and are able to incorporate the impact these changes have for the company at an early stage. Stora Enso is an example of this.

\section{Foreseeing environmental regulation}

Stora Enso, a Finnish paper producer based in Finland and Sweden, had its paper mills Swan labelled in 1994. As a part of meeting the criteria of the Swan Label the company had to invest in COD (chemical oxygen demand decreasing equipment). However, Stora Enso could meet future regulation regarding COD equipment at an early stage and saw an advantage in getting Swan labelled and being at the forefront of the development.

\subsection{Wishing to streamline the production with the Swan Label}

The decision to become Swan labelled is also for some companies taken with the purpose of using the Swan Label as a driver for change in the company and as a tool for changing processes. For most product groups the companies report their usage of resources - i.e. water, heat, electricity, etc. - into an online based system as part of the process of becoming Swan licensed. Having the Swan Label, thus, provides the companies with an overview of their costs and expenditures and gives them a possibility to focus on these expenditures and to change, restructure and professionalise workflows, routines, etc. in the company. The Swan Label can in some cases, thus, be used as a means for restructuring internal processes. 


\section{The implementation of the Swan Label}

This section takes a closer look at companies' implementation of the Swan Label. This is done to better understand how companies work with the Swan Label in the company and the consequences it has for the different departments and employees. In connection with this the costs and barriers as experienced by the companies during the implementation phase are examined.

\subsection{The companies' approach}

The companies interviewed have implemented the label in relatively similar ways. For many companies, the decision to acquire the label has been a strategic choice taken at the management level as a response to growing consumer pressure (or pressure from other companies if the company operates on the business-to-business market). How they experience this increasing pressure varies between the companies. Some companies experience concrete requests from clients while others register a growing focus in media and other communication channels, whereas others again experience a growing focus on the environment as a part of the selection criteria in public tenders. For some companies it is important to be a first-mover, while others are following a general trend within their segment.

Companies usually apply a top-down approach when implementing the Swan Label. Two different approaches in terms of the practical implementation can be observed; 1) delegation of the responsibility of implementing the label to one person or department and 2) setting up a working/project group of people responsible for implementing the label.

For companies labelling a service or an entire company (e.g. hotels) the management typically organises a working-group with representatives from various departments, e.g. from housekeeping, marketing, technical services, etc. The working group is responsible for documentation, registration and implementation of the necessary measures or 
changes throughout the entire organisation. An example of this can be seen in the box below.

\section{Implementation of the Swan Label at Holmenkollen Rica Hotel Oslo}

The manager of Holmenkollen Rica Hotel initiated the labelling process, but a working group represented by housekeeping, marketing, technical services, etc. was responsible for the practical implementation. The manager argues that it was important that the entire organisation worked together in order to comply with the criteria and it was central that the working group included engaged employees with sufficient decision making power ensuring that necessary steps were taken.

For some of the companies Swan labelling a product the responsibility for the registration process was given to one employee. This employee had the responsibility of implementing and collecting the necessary documentation and data from the entire organisation. Commonly, the implementation process involved staff from sales and marketing as well as the production.

Over time, the Swan Label becomes a part of the companies' routines and internal processes. While some companies heavily market the Swan Label internally (making sure that all employees are aware of the Swan Label at all times), most companies will tend to implement the criteria of the Swan Label as much as possible into regular routines. The label becomes an integrated part of the organisation and the development of new products and services.

\subsection{Success requires motivation and commitment}

The interviews have shown that the companies which are successful in implementing the Swan Label all have employees as well as management which are committed to the acquisition and implementation of the Swan Label.

\subsubsection{Staff motivation is evident for success}

In order to achieve a successful implementation it is essential for companies that the entire organisation works committedly on implementing the Swan Label. This is particularly important for companies certifying a service as this often requires more drastic changes for the entire organisation. 
Only few of the companies interviewed have experienced negative reactions from the staff towards the implementation of the Swan Label. The negative reactions occur because changes have to be made in the specifications of a product or in working practices and routines. As an example, some companies experienced negative reactions from the staff because the company changed the way in which it separates its waste. Others also experienced frustrations due to the detailed documentation requirements. However, most companies argue that if you manage to explain and justify why the Swan Label and the changes which comes with it are important, the staff in general has been very positive and worked together to implement the necessary steps.

\subsubsection{Management commitment and persistence is important}

In order to achieve a successful implementation of the Swan Label, the companies emphasise that it is also important to have backing from the management. Almost all of the companies interviewed as a part of this study argued that the initiative came from the management; however, it is important that this backing persists throughout and even after the implementation. This is particularly important as a company relatively quickly experiences an increase in costs in terms of fees and man-hour, whereas the positive impacts are experienced at a later stage.

The companies being most successful in implementing the Swan Label are those which manage to communicate the advantages of the Swan Label to all parts of the company and to all employees involved. In particular, these companies focus on making it clear for the employees how the changes following from the Swan Label are positive for their job position and daily work. The concept of change management and being able to make the employees see the advantage of the Swan Label is important in order to gain success.

\subsection{Costs of the Swan Label}

The following section looks closer at the costs of acquiring the Swan Label. There are direct costs of having the Swan Label in the form of application fees, renewal fees, etc. However, the most significant costs stemming from the Swan Label are indirect. 


\subsubsection{Direct costs}

Companies wishing to acquire and implement the Swan Label are obliged to pay various types of fees. First of all, the companies have to pay an application fee covering the costs of administering and processing the application at the ecolabelling offices. For all of the five Nordic countries the fee is approximately EUR 2,000 (varying slightly due to exchange rates) for all types of companies. However, a discount is given to smaller companies which pay approximately EUR 1,000.

Secondly, the companies pay a renewal fee whenever the criteria for their particular product group are updated and they have to re-apply. This fee is approximately EUR 1,000 for all companies while smaller companies pay approximately half.

Extension fees are paid by the companies when they wish to expand or make changes to their current license. These fees are (except in Iceland) dependent on the number of hours used from the side of the ecolabelling office.

Table 3: Application fees, renewal fees and expansion fees

\begin{tabular}{|c|c|c|}
\hline Country & Type & The Swan Label \\
\hline \multicolumn{3}{|l|}{ Iceland } \\
\hline & Application & Micro enterprises $=$ EUR 1,000, Other enterprises $=$ EUR 2,000* \\
\hline & Renewal & Micro enterprises $=$ EUR 500, Other enterprises $=$ EUR $1,000 *$ \\
\hline & Extension/changes & All enterprises $=$ EUR $245^{*}$ \\
\hline \multicolumn{3}{|l|}{ Denmark } \\
\hline & Application & Micro enterprises $=$ EUR 1,000, Other enterprises $=$ EUR 2,000* \\
\hline & Renewal & Micro enterprises = EUR 500, Other enterprises = EUR 1,000 \\
\hline & Extension/changes & $\begin{array}{l}\text { All enterprises: } 1 / 2 \text { working day = EUR } 250,1 \text { working day = EUR 500, } \\
\text { more than } 1 \text { working day = EUR } 1,000\end{array}$ \\
\hline \multicolumn{3}{|l|}{ Norway } \\
\hline & Application & Micro enterprises = EUR 1,000, other enterprises $=$ EUR 2,000* \\
\hline & Renewal & Micro enterprises $=$ EUR 500, other enterprises $=$ EUR $1,000 *$ \\
\hline & Extension/changes & $\begin{array}{l}\text { All enterprises: } 1 / 2 \text { working day = EUR } 270,1 \text { day = EUR } 535 \text {, more than } 1 \\
\text { day = EUR } 1,070\end{array}$ \\
\hline \multicolumn{3}{|l|}{ Sweden } \\
\hline & Application & Micro enterprises $=$ EUR 1,000, Other enterprises $=$ EUR 2,000* \\
\hline & Renewal & Micro enterprises $=$ EUR 500, Other enterprises $=$ EUR $1,000 *$ \\
\hline & Extension/changes & $\begin{array}{l}\text { All enterprises: } 1 / 2 \text { working day = EUR } 295,1 \text { day = EUR 590, more than } 1 \\
\text { day = EUR } 1,185\end{array}$ \\
\hline \multicolumn{3}{|l|}{ Finland } \\
\hline & Application & Micro enterprises = EUR 1,000, Other enterprises = EUR 2,000* \\
\hline & Renewal & Micro enterprises $=$ EUR 500, Other enterprises $=$ EUR 1,000 \\
\hline & Extension/changes & $\begin{array}{l}\text { All enterprises: Fees for changes = EUR 0-1,000, depending on working } \\
\text { hours }\end{array}$ \\
\hline
\end{tabular}

Source: Websites of the national ecolabelling offices. Note: *Currency converted, $28^{\text {th }}$ February 2013. The application fees are set to EUR 2,000 in all countries although exchange rates vary and have an influence of the final price paid in national currency. 
Furthermore, the companies carrying the Swan Label have to pay a yearly fee. The fee is the same in all countries: typically 0.3 per cent of sales of a Swan labelled product per year and 0.15 per cent of the turnover of Swan labelled services per year. It should be noted, however, that some variation occurs across product groups (not shown).

\begin{tabular}{|c|c|c|}
\hline Country & Type & The Swan Label \\
\hline \multicolumn{3}{|l|}{ Iceland } \\
\hline & Products & Most products $=0.3 \%$ of net sales of the product per year \\
\hline & Services & Most services $=0.15 \%$ of the turnover of service per year \\
\hline \multicolumn{3}{|l|}{ Denmark } \\
\hline & Products & $\begin{array}{l}\text { Most products }=0.3 \% \text { of the turnover of Nordic ecolabelled } \\
\text { products }\end{array}$ \\
\hline & Services & $\begin{array}{l}\text { Most services }=0.15 \% \text { of the turnover of Nordic ecolabelled } \\
\text { services }\end{array}$ \\
\hline \multicolumn{3}{|l|}{ Norway } \\
\hline & Products & $\begin{array}{l}\text { Most products }=0.3 \% \text { of the turnover of Nordic ecolabelled } \\
\text { products }\end{array}$ \\
\hline & Services & Most services $=0.15 \%$ of the turnover of service per year \\
\hline \multicolumn{3}{|l|}{ Sweden } \\
\hline & Products & $\begin{array}{l}\text { Most products }=0.3 \% \text { of the turnover of Nordic ecolabelled } \\
\text { products }\end{array}$ \\
\hline & Services & Most services $=0.15 \%$ of the turnover of service per year \\
\hline \multicolumn{3}{|l|}{ Finland } \\
\hline & Products & $\begin{array}{l}\text { Most products }=0.3 \% \text { of the turnover of Nordic ecolabelled } \\
\text { products }\end{array}$ \\
\hline & Services & Most services $=0.3 \%$ of the turnover of service per year* \\
\hline
\end{tabular}

Source: Websites of the national ecolabelling offices. Notes: Turnovers up to EUR 20 million. Should the turnover exceed this amount, a license fee of 0.05 per cent of the turnover will be charged.

The fees of the Swan Label are being harmonised across the Nordic countries and as the above shows, only few differences exist.

\subsubsection{Indirect costs and barriers}

Besides the direct costs of acquiring the Swan Label a number of indirect costs are faced by the companies with respect to implementing the Swan Label. These indirect costs are often considered to be larger than the direct costs. However, none of the interviewed companies have a complete overview of these costs and have actually measured all of them. 
The number of indirect costs experienced as well as the magnitude of these varies across companies.

As described in the chapter on hypotheses the indirect costs hypothesised to be experienced by the companies before interviewing them were:

Table 5: An overview of the expected costs incurred by the Swan Label

\begin{tabular}{ll}
\hline Type of cost & Examples of indicators \\
\hline Indirect costs & Time used on the application procedure \\
& Changes in the production (higher or lower costs) \\
& Higher costs of raw materials and input into the \\
production & \\
Investments in new technology & Assistance from consultants \\
Education or training of employees
\end{tabular}

Source: DAMVAD, 2013.

All of these indirect costs have been confirmed to appear by the interviewed companies. However, the magnitude and number of costs to incur differs to a large extent across companies.

Several of the companies interviewed apply other environmental initiatives than the Swan Label in the company or certain parts of the company. Other ecolabels, the company's own environmental policy and in particular standards such as ISO 14001 play a significant role. They do this because they constantly seek to minimize the use of environmentally harmful products and materials and wish to substitute when alternative products and materials are available. The companies either see this as a part of their social responsibility or are "forced" to react on national or international regulation. With such initiatives companies strive to reduce the use of energy, water and waste and they are not able to directly link the savings, increases in costs or changes in processes to one initiative or the other. Thus, for many of the companies the Swan Label is an integrated part of their environmental efforts alongside several other initiatives (see an example of this in the box below).

\section{The Swan Label as one of several initiatives}

Stora Enso, a Finnish paper producer, describes how the Swan Label is one of several initiatives within the company's effort to be environmentally friendly. Besides the Swan Label and the EU Ecolabel the company has implemented several environmental standards. All these initiatives contribute with environmental improvements and it is difficult for the company to pinpoint exactly which impact one or the other is responsible for. 
The most often stated indirect cost relates to an increase in the use of man hours related to the collection of necessary documentation. Some companies also experienced an increase in production costs as they need to find new materials and suppliers. Many argue that staff engagement and management commitment are important success factors, very few, however, have seen this as a barrier or a cost.

\section{The application procedure is time consuming}

Nearly all of the companies interviewed find the collection of documentation challenging and time consuming. For companies seeking to certify a particular product the main use of man-hours is related to the need to learn about the criteria and collect documentation. Companies seeking to certify a service furthermore need to put additional hours in measuring and reducing resource usage. As an example a hotel stated that they had to count, measure resource usage and replace several hundred light bulbs and shower heads.

Further, all companies argue that as a part of the collection of the necessary documentation the companies have had to engage in closer communication and dialogue with suppliers and subcontractors. See the case description of Delipap Oy on the following page for an example of this.

Some companies point to the fact that they needed to build competence about their own production and input factors in order to understand the criteria and to collect the necessary documentation. One of the interviewed furniture producers realised that they knew little about the consequence that textile colouring had on water quality before they needed to document this as a part of the Swan process. Others state that it was difficult to measure the total use of certain types of chemicals as the suppliers did not give the chemical content away (as it is considered a company secret).

All of these aspects result in an increase in man-hours for the companies involved. Most companies expected that acquiring the label would require some man-hours, but most say that it was more time consuming than first anticipated. Even if resources were allocated to the implementation process, many companies experienced that they did not allocate enough time to the process, causing some initial frustration. The Danish company Dyrup exemplifies this. 
Implementing the Swan Label can be time consuming

Dyrup, a Danish (now American owned) producer of paint, licensed one of its products with the Swan Label. However, the process of getting the product licensed was far more tedious than expected and the process took several months of communication back and forth. The company estimates spending more than 100 hours on this. Part of the reason for this was that the product was already licensed with the EU Ecolabel and when changing the "recipe" for the product to have it Swan labelled the company had to re-apply to have the product labelled with the EU Ecolabel. 


\title{
Case: Delipap Oy - Finland
}

\author{
Motivation \\ Delipap Oy got its diapers Swan labeled in 2006 and its \\ sanitary towels in 2010. The company has traditionally \\ had a strong focus on being environmentally friendly and \\ believed that the Swan Label fitted well into the \\ company's profile. \\ The decision was, however, primarily driven by the \\ demand from a large private label customer. The \\ company, furthermore, saw it as an opportunity to \\ differentiate themselves from the competitors on the \\ market and communicate certified environmental \\ responsibility towards their customers.

\section{About Delipap Oy} \\ Delipap Oy is the only Finnish producer of \\ feminine hygiene products and baby diapers. \\ The company was founded in 1978. All \\ production is situated in Finland, on top the \\ company has a sales subsidiary in St. \\ Petersburg in Russia. \\ Employees: 70. \\ Location: Feminine hygiene plant and head \\ office, Veikkola, Finland. \\ Diaper plant, Tammisaari, Finland \\ Implementation \\ The implementation of the Swan Label took approximately one year and the responsibility was held by the \\ CEO and a project manager hired for the purpose of the implementation. The implementation of the Swan \\ Label at Delipap Oy involved purchasing partly completely new raw materials for the production as these \\ had to be changed in order to live up to the criteria of the Swan Label. Delipap Oy asked the subcontractors \\ to report usage of chemicals in their products and information about their production processes overall. \\ The Swan licensing process led to an exchange of some subcontractors while others had to exchange the \\ input materials sold to Delipap Oy. The company now has fewer raw material subcontractors to choose \\ from. This has made the access of raw material more difficult and in some circumstances more expensive. \\ Impact \\ When Delipap Oy became Swan labeled they started step by step to change the packaging of their products \\ and included the Swan label. At the same time they also changed the concept of the products towards a \\ more environmentally responsible niche and introduced a completely biodegradable range. The company, \\ thus, finds it difficult to pinpoint the exact impact of the Swan Label on sales. However, Delipap Oy \\ considers the Swan Label to be a central part of their brand concept and to some degree find that they can \\ differentiate themselves by having the Swan Label. It is a credible way to communicate both towards \\ customers and consumers that they take their environmental responsibility seriously.
}
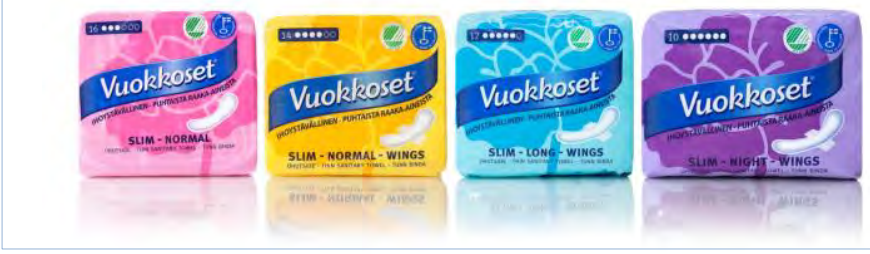

After the first implementation, the Swan Label and its requirements generally become integrated parts of the organisation, involving all departments from research and product innovation to production and sales and marketing. As the companies build competence and experience and streamline the registration and documentation process the use of human resources diminish. Thus, most companies argue that it gets easier with time, as the company and its suppliers are familiar with the criteria. 


\section{The Swan Label has consequences for the production and production costs}

For some of the interviewed companies the Swan registration and implementation has led to indirect costs in terms of investments in energy saving measures, waste facilities (see example in the box below) or new production machinery. This e.g. happens when a production company has to change its machinery in order to handle a new type of material which now has to be used because of the Swan criteria or when a printing company, over time, has to change its printing machinery towards new equipment which is environmentally friendlier.

\section{Investment in waste facilities at Holmenkollen Rica Hotel Oslo}

As a part of the Swan registration process the hotel has implemented several measures to reduce and optimize its waste handling procedures. Changes were made to the routines related to separation of waste in the kitchen, reductions in waste by reducing the use of single-packages (e.g. shampoo, butter and marmalade) and by investing in a composting system. As a result of the latter, the hotel now uses its biowaste for fertilization. As a result, the hotel has reduced its amount of waste by 14 per cent in 2012 compared with 2007 and half of the costs of waste disposal (despite a 50 per cent increase in capacity).

Many companies describe how it is necessary to engage in a closer dialogue and surveillance of suppliers and subcontractors than before. Furthermore, several of the interviewed companies state that they have had to identify new suppliers or subcontractors because the former did not meet the new requirements following from the Swan Label. Moreover, many companies had to change the input materials to new materials complying with the Swan criteria. These situations often lead to increases in production costs making Swan labelled products more expensive than they otherwise would have been. In some cases, however, the replacement is considered too costly or difficult, and they decide not to certify certain products as Swan labelled products. Both producers of paint, detergents and furniture report rising production costs as a result of the Swan Label.

However, several companies argue that the difference in costs diminishes over time as the more environmentally friendly inputs become more competitive and increase their market shares. An example of the above can be seen in the box. 


\section{Changes and costs following the Swan Label}

Grand Hotel Reykjavik in Iceland changed a number of processes throughout the hotel and had to exchange some products for others while other products and services could be dropped without exchanges. In some areas the hotel now has fewer suppliers to choose from resulting in fewer choices and in some occasions higher costs.

\section{Companies hire consultants for the implementation of the Swan Label}

While most companies manage to implement the Swan Label using their own employees and effort other companies decide to seek assistance for the implementation. These companies will hire consultants specialising in implementing the Swan Label and other ecolabels and environmental initiatives. A few of the companies interviewed have also sought help from their business association. The fees for this assistance can be said to be an indirect cost of the Swan Label.

The dialogue with such consultants or business organisations usually starts by identifying which ecolabel is needed. Often, companies consider acquiring either the Swan Label or the EU Ecolabel (the Flower) and decide in cooperation with the consultant which of them is the most relevant. Considerations regarding the costs play a role here but the most important factor is the knowledge of the ecolabelamong the customers to the products or services. Vester Kopi is an example of this.

\section{Implementing the Swan Label with the assistance of consultants}

When deciding to acquire an ecolabel Vester Kopi contacted its business organisation for assistance. Initially, the business organisation helped the company to establish which Label to acquire - a choice between the EU Ecolabel and the Swan Label. After going through potential costs and benefits the company decided to go for the Swan Label. A plan for implementing the Swan Label and the consequences in each step was developed in cooperation with the business organisation.

\section{Companies use the opportunity to train their employees}

Only a few of the interviewed companies find that the Swan Label leads to increased costs for education or training of the employees. These companies use the implementation as a driver for changes in the production or other work routines and use the opportunity to update the knowledge of their employees on these processes. As such, the size of this cost is probably minor as the companies get an advantage out of the training. This is described more thoroughly in the chapter on impacts below. 


\section{The impact and benefits of the Swan Label}

In this section the impacts experienced following the introduction of the Swan Label as described by the interviewed companies are presented. Thus, after examining the motivational factors for the companies to acquire the Swan Label and the implementation of the label, including the barriers and challenges met, this chapter sets its focus on the impacts which the Swan Label leads to.

Most companies seem to value the positive effects larger than the negative effects (costs). However, the interviews show that very few companies systematically measure the effects of having the Swan Label. The perception is that "it pays off". It is, furthermore, an observation that the effects of having the Swan Label differs quite substantially from company to company and across company size, industry, etc. As a result of this it is impossible to pinpoint general effects which can be said to be true for all companies. In the following the effects having been identified will be presented but it is important to keep in mind that not all effects can be seen for all companies.

All of the interviewed companies particularly point out that the Swan Label makes it easy to communicate and market the environmental work that the company is doing (either as a result of applying for the label or independent of the label). Not all of the companies believe that the label has brought an increase in sales, particularly as more and more companies within the same market segments are labelled. However, many recognise that sales might have gone down if they did not have the label. This is particularly the case for companies in Business-to-business markets as some of their customers (private and public) demand that the products or services have some kind of eco certification.

A subset of the companies interviewed can document large reductions in costs and positive effects on work well-being in the company while others to a lesser extent believe that the use of the label has reduced costs or had a positive effect on work well-being or possibilities for hiring new employees. Others again experience one or few of the mentioned types of effects below. On the contrary, another subset of the 
companies argues that the use of the label tends to increase the overall production costs (see above).

For companies that have Swan labelled their service (hotels, dry cleaners, printing facilities etc.) the introduction of the Swan Label has brought significant effects on resource efficiency such as usage of water, energy and waste, but also on the use of chemicals and other inputs to products and materials. Companies that only label certain products also point to changes in input factors, but the effect of the Swan Label is more difficult to measure and relate to the Swan Label in these cases.

\subsection{The Swan Label's impact on the value chain}

As described earlier, the Swan Label can affect the value chain and put pressure on some companies to be environmentally friendly while some companies use the Swan Label to put pressure on their subcontractors. The different pressures on the value chain coming from the Swan Label are described below.

Firstly, companies having the Swan Label are required to use environmentally friendly inputs. Accordingly, these companies put pressure on their subcontractors to deliver environmentally friendly inputs or semi-finished goods to be able to fulfil the Swan criteria. This is illustrated in the figure below:

Figure 2: Swan labelled companies put pressure on subcontractors to be more environmentally friendly

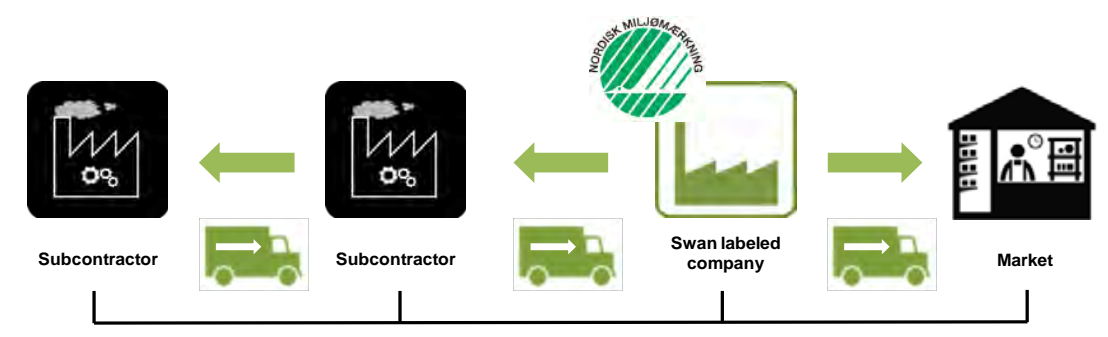

Note: Design and idea adapted from DAMVAD (2013): “Standarder som værdiskaber i danske virksomheder".

Naturally, some companies experience this pressure from their customers (other companies) and are "forced" to either acquire the Swan Label or become more environmentally friendly in other ways to be able to keep these as customers. An example of this is Norwegian Storebrand. 


\section{Pressure leads to the introduction of the Swan Label}

Norwegian Storebrand, a leading player in the Nordic market for pensions and insurance, used the Swan Label as a prerequisite for the purchase of new products when they built their new office location in Oslo in 2007. At the time there were no Swan labelled office chairs on the market but two major office chair produces took the initiative to develop Swan criteria for office chairs alongside the national Swan licence office. Shortly after, companies started to develop and produce Swan labelled office chairs.

This type of pressure is illustrated in the following figure:

Figure 3: Swan labelled companies put pressure on subcontractors to acquire the Swan Label

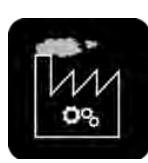

Subcontractor

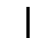

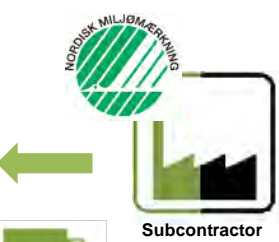

Subcontractor labeled
laming

1

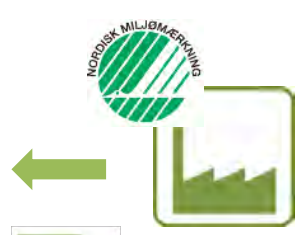

Swan labeled company

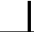

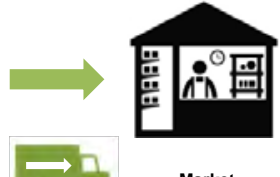

Market

Note: Design and idea adapted from DAMVAD (2013): “Standarder som værdiskaber i danske virksomheder".

Finally, some companies also experience a pressure from the consumers, demanding more environmentally friendly products and services. These companies use the Swan Label as a stamp of approval for their products. This principle is illustrated below:

Figure 4: Consumers demanding Swan labelled products/services puts pressure on companies to become Swan labelled

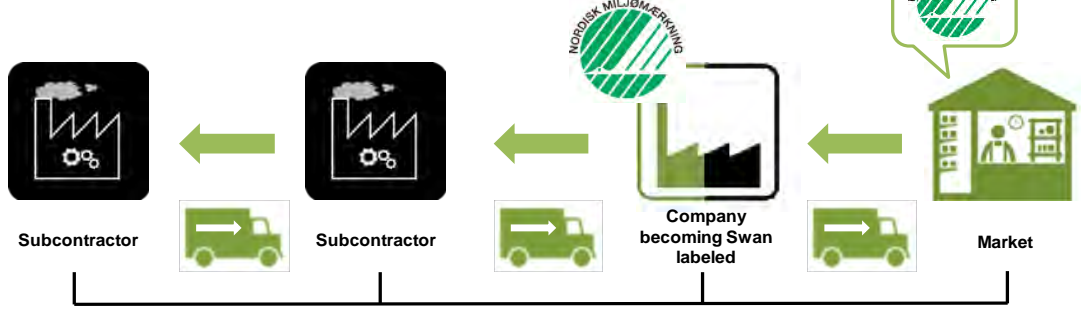

Note: Design and idea adapted from DAMVAD (2013): “Standarder som værdiskaber i danske virksomheder". 
Several of the companies interviewed explain how they were firstmovers in their market and gained an advantage from this in the first years. These companies use the Swan Label as a way to differentiate their products or services from their competitors' offers. However, often competitors follow up and become Swan labelled which reduces the competitive advantage of being the first mover (more on this below).

\subsection{The impact on marketing and branding}

Regarding marketing and branding the hypothesis is that having the Swan Label will give a product or a company a green, trustworthy credibility towards consumers and that environmentally concerned consumers specifically will be searching for and selecting Swan labelled products or companies. Another hypothesis is that the Swan Label strengthens the positioning of a company and its products or services towards professional, public buyers. Finally, it is hypothesised that the Swan Label can have spill-over effects to the company's brand and signal environmental consideration to a higher degree than otherwise.

Table 6: Hypothesis regarding the Swan Label's impact on marketing and branding

\begin{tabular}{ll}
\hline Hypothesis & Causal relationship \\
\hline $\begin{array}{l}\text { Impact on marketing and branding } \\
\begin{array}{l}\text { The Swan Label strengthens the } \\
\text { ing in their markets }\end{array}\end{array}$ & $\begin{array}{l}\text { The Swan Label gives a product/service an "environmental trust- } \\
\text { worthiness" among consumers }\end{array}$ \\
& $\begin{array}{l}\text { Environmentally concerned consumers will deliberately pick Swan } \\
\text { labelled products/services }\end{array}$ \\
& $\begin{array}{l}\text { The Swan Label reduces the risk of bad exposure } \\
\text { buyers, e.g. the public sector }\end{array}$ \\
The Swan Label supports CSR-activities \\
The Swan Label can result in spill-over effects towards the brand of \\
the company, as well as the company's other products/services
\end{tabular}

Source: DAMVAD, 2013.

\subsubsection{The Swan Label strengthens the environmental profile of the companies}

Many companies point out that the Swan label has positive impacts on sales and marketing. First of all, the Swan Label makes it easy to communicate and market the environmental work that the company is doing. Companies underlining this also highlight that the label is a good 
way to communicate the environmental profile of the company and its products and services in a more efficient and credible way than the company's own self-developed documentation forms. For some, the label is purely seen as a "proof" of the work they already do. For others, the label is a proof of the changes they have done. One company describes the Swan Label as [a] "signal to the consumer that we put action behind our words."

Several companies describe how the Swan Label has improved their environmental profile and given them better exposure towards their customers. The Swan Label improves the marketing possibilities and signals quality and responsibility. An example of this is Swedish company Ballograf.

\section{Creating awareness with a Swan Labelled pen}

Ballograf, a Swedish producer of pens and other markers, decided to introduce a Swan labelled pen to the market. As the first Swan labelled pen on the market, this created a significant amount of awareness and ensured them good publicity in magazines and brochures.

All companies interviewed are using the Swan Label in their own marketing alongside the marketing of their products' other characteristics. Some companies incorporate the Swan Label very thoroughly in their marketing and build their brand "around" the Swan Label while others include the Swan Label as a part of their profile, brand and characteristics. For many companies the Swan Label plays an important part of the companies' other activities within environmental awareness and CSR. The Swan Label becomes part of the initiatives the company otherwise has, such as an environmental policy. Furthermore, the Swan Label is used by many companies as a way of differentiating themselves from competitors and a way to position the company as unique. Many of the companies interviewed use substantial resources on marketing and branding after having acquired the Swan Label and rely heavily on the Swan Label's well-known brand. These companies choose to increase their spending on marketing and advertising and advertise their Swan labelled products and services heavily. 
Figure 5: The Swan Label as an integrated part of the branding

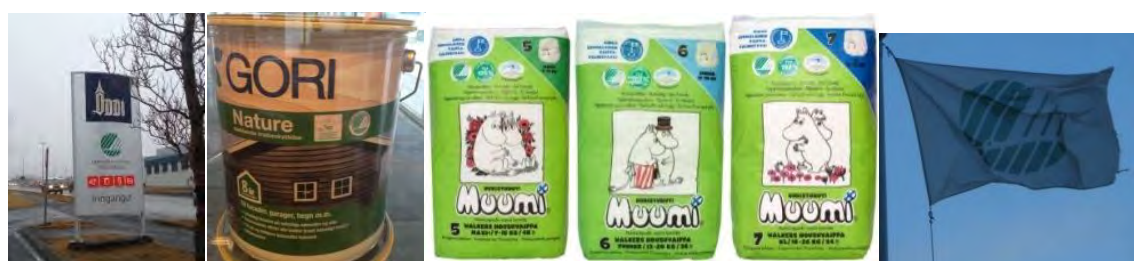

Note: Pictures from Oddi (see www.oddi.is), Dyrup (see www.dyrup.dk), Delipap Oy (see www.delipap.fi) and Grand Hotel Reykjavik (see www.grand.is).

Companies in market segments with many Swan labelled products often consider the label as a required factor and something they need to have. Even if it is important to have an ecolabel, these companies also focus on their own brand to create loyalty and consumer confidence.

\subsubsection{The Swan Label is a prerequisite for sales}

As described above most of the interviewed companies highlight market pressure as a dominant motivation for the registration of their product under the Swan Label. Some companies experience this as a clear pressure from private consumers and public opinion due to a growing recognition of the negative environmental effects of certain products. Companies in professional markets (Business-to-business) experience a rising pressure due to a growing focus on the environment as a part of criteria for public procurement routines or because their costumers (other companies) have an environmental profile as a part of their business strategy. Duni (see box below) is an example of this. Many companies, furthermore, argue that the Swan Label has become a market standard within their field and that they would not be able to sell their products without the Swan Label.

\section{The market demanding the Swan Label}

For DUNI, a Swedish producer of napkins and candles licensed in 1998 and 2008 respectively, the reason for having the Swan Label is clear. There is a market demand from the hotel and restaurant markets in which they operate for the products to be Swan licensed - having the Swan Label has become a market standard and a prerequisite for selling. 


\subsubsection{The Swan Label is one of several selling points}

The direct impact of the Swan Label on the sales of products and services is difficult to measure for the companies and the size of the impact differs from company to company.

Some companies indicate that the Label resulted in increased sales and new customers. Others find that they have been able to target new segments of customers which they could not before the Swan Label while others again state that the Swan Label has not increased sales or attracted new customers.

Most of the interviewed companies describe how the Swan Label is one of several selling points which they offer through their products or services. Thus, they find it difficult to pinpoint the direct impact or value of the Swan Label as other factors such as price, quality, type of customer, packaging, consumer awareness, etc. play important roles as well. Thus, the Swan Label is part of the "package" for many companies. An exemplification of this can be seen in the box below regarding the Norwegian company Jensen.

\footnotetext{
Jensen bed and mattresses producer in Norway

Jensen is one of the leading bed and mattresses producers in Scandinavia with a production of more than 150,000 units each year. Jensen produces high-quality mattresses in a market with growing competition from other high-end producers and low cost producers. Jensen views the Swan Label as part of the social and environmental profile but find that consumers mostly care for price and quality. Other "hygiene factors" such as 25 years of warranty have a larger sales effect than the Swan Label. As long as their competitors are Swan labelled they fear that they will lose sales if they stop using the label.
}

Some companies find that the label alone has not brought the increase in sales as expected and hoped for beforehand. Some argue that although customers now know more about the negative environmental effects of certain products, they are less willing to actually pay for the benefit of knowing that the company is doing all it can to reduce the negative effects. Other companies, however, find that they can charge higher prices for their products or services due to the environmental advantages of these. For some companies this is a necessity as production costs have increased due to the Swan Label.

Over time, as many more products and companies are labelled, some companies find that the label loses its importance as a selling point. However, the same companies communicate that they does not see it as 
an option not to have the label because they fear that this will have negative effects on sales (as described above).

Some companies also see that there has been a growing demand from municipalities and other public authorities to document their environmental work as a part of the tendering process. Having some kind of ecolabel can facilitate and simplify the communication and documentation, and thus increase sales or prevent that sales drop. The same companies also highlight that only a few companies or public authorities demand that the supplier need to offer Swan labelled products, and that other ecolabels (such as the EU Ecolabel) or documentation could be sufficient. For example, within the hotel industry where the largest hotel chains are labelled, the label is not in all cases considered as important as price, location and facilities are, but hotels might lose out on the competition if they do not have the Swan or any other ecolabel. Both hotels and printing companies describe how they are now able to participate in more public tenders as they can offer "green meetings" or printing on environmentally friendly paper and with environmentally friendly methods.

\subsubsection{The Swan Label improves documentation}

Only a few companies have experienced that the labelling process has led to a reduction in customer complaints. However, many experience that the company is in a better position to answer more specific questions (for example related to allergy) than before. The reason for this is that the companies, as a result of the registration process, have acquired more knowledge about their own products and the input materials which they can share with the consumers.

\subsection{The impact on HR and recruitment}

Regarding HR and recruitment it was prior to the analyses hypothesised that employees are more motivated when working for companies taking environmental and societal responsibility. The Swan Label is expected to have a positive effect on the attractiveness of the company as a workplace. Furthermore, it is expected that the acquisition of the Swan Label can have a positive effect on some companies' work well-being due to reductions in chemicals and similar dangerous substances. 
Table 7: Hypothesis regarding the Swan Label's impact on HR and recruitment

\begin{tabular}{ll}
\hline Hypothesis & Causal relationship \\
\hline $\begin{array}{l}\text { HR and recruitment } \\
\text { ability to recruit, retain and motivate } \\
\text { employees }\end{array}$ & $\begin{array}{l}\text { Employees are more motivated in companies taking a social } \\
\text { responsibility }\end{array}$ \\
& $\begin{array}{l}\text { The social responsibility strengthens the company's attractive- } \\
\text { ness as a work place }\end{array}$ \\
& $\begin{array}{l}\text { Improved work well-being, e.g. as a result of handling less dan- } \\
\text { gerous chemicals }\end{array}$ \\
& $\begin{array}{l}\text { Possibilities for courses and other types of qualification for the } \\
\text { employees }\end{array}$ \\
\hline
\end{tabular}

Source: DAMVAD, 2013.

\subsubsection{The Swan Label plays a minor role when it comes to recruiting}

Most of the interviewed companies argue that the Swan Label has not brought any direct positive changes in aspects related to recruitment of employees. There might be various reasons for this, one being that there are many other factors that are important when people decide on a job position (salary, location, activity, management etc.). Another reason can be that it can be difficult to measure the exact impact the Swan Label has on the decision to take a certain job.

However, most of the companies interviewed argue that it is their experience that the overall environmental profile of the company is important for many employees and the Swan Label plays an important role for most companies in this context. Thus, when it comes to recruiting as well as retaining employees many companies interviewed find that having the Swan Label and being environmentally responsible makes employees proud of their workplace.

Some companies also find that their employees become very engaged in the process of acquiring the Swan License and are enthusiastic about their part in making the company green. Also, if the process has brought increased attention and recognition of the work that some of the employees are doing, the Swan can have a positive impact.

Some of the companies interviewed seem to record that there has been some immediate dissatisfaction amongst the employees, particularly if they were forced to change their work routines, or if they were asked to collect a significant amount of documentation. Often the registration process is more demanding than first realised for the companies and creates additional work for some of the employees. With time, how- 
ever, the registration and documentation process is more integrated and a defined part of someone's work and less time consuming.

\subsubsection{The Swan Label as an internal marketing tool}

The interviews also show that the companies differ in the way that the Swan Label is marketed internally. All companies that have had the Swan Label for some time argue that the label and its criteria has become an integrated part of the entire organisation with a direct effect on choices taken during product development, training of the staff and sales and marketing. In general, the companies incorporate all changes resulting from the Swan Label in the organisation's and, thereby, the employees' routines and tasks. Thus, for some companies the presence of the Swan Label is not something which the employees have in mind or pay special attention to. Furthermore, for some companies the Swan Label is merely used for documentation purposes and changes in the production might be very limited if the company is environmentally friendly in advance.

Other companies, however, also choose to market their environmental profile and the Swan Label extensively inside the company. They use it to create awareness among the employees and to drive a change in internal processes and routines in the company. One example of such a company is Oddi (www.oddi.is), a printing company in Iceland. The company has, among other things, created awareness of the Swan Label by using large posters in the production areas of their facility reminding employees about the positive impacts of the Swan Label.

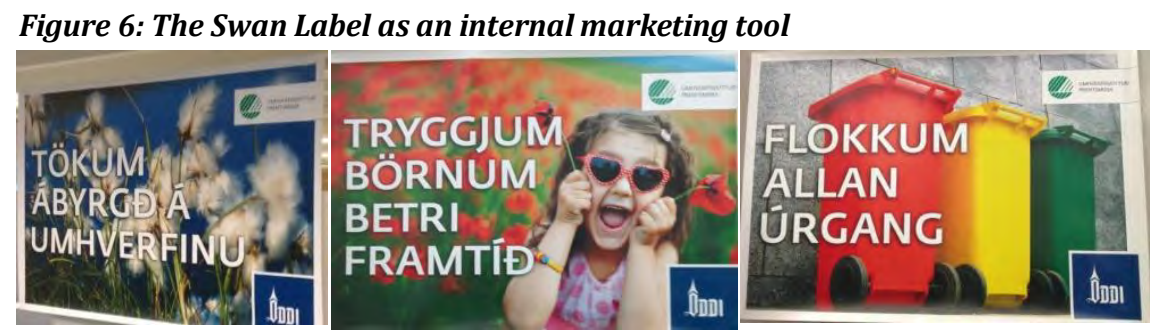

Note: Pictures from Oddi (see www.oddi.is).

Even if it is difficult to measure exactly how the employees feel about the Swan Label, the interviews show that to a certain extent some employees are content about the fact that their organisation is doing what it can to reduce the negative environmental effects. Some have also stated that, even if it is small steps they are happy to contribute to a "better world". 


\subsubsection{The Swan Label has a positive impact on work well-being}

For the companies interviewed using chemicals or similar substances the Swan Label had a positive impact on work well-being. Because of the Swan Label criteria these companies are "forced" to change the chemicals or materials in their products which are not environmentally friendly. For their employees this often results in an improved work wellbeing as these chemicals can have negative impacts causing allergies or serious injuries when treated wrongly.

Several of the companies, thus, report how removing substances from their production facilities has led to a better work well-being environment and atmosphere for their employees to work in. Furthermore, these changes occasionally lead to cost reductions for the companies when they can avoid replacing the previously used chemicals with other chemicals or when new materials are less costly (more on this below). See examples of this in the following box,

\section{Removing substances and dangerous materials}

Particularly companies that use chemicals in the production of goods or services argue that the Swan has led to better work conditions. This is e.g. the case for producers of detergents and paint. Undri, and Icelandic soap producer, removed a chemical from one of its products following the Swan licensing process. This led to a better work environment as the production area no longer has the odour of the previously used chemical.

Some hotels have also implemented measures which reduced the need to use chlorine. Rica Holmenkollen Hotel in Oslo has, through the investment in advanced filters, reduced the use of chlorine in the cleaning of shower heads.

\subsection{The impact on the use of resources}

Another hypothesis is that the Swan Label leads to a more efficient use of resources, e.g. less water or energy use and reduced waste disposal among the companies. Furthermore, the Swan Label was expected to influence companies' production processes and the effectiveness of such processes. Finally, the Swan Label was expected to be able to lead to an optimisation of the value chain with a focus on quality and the environment. 
Table 8: Hypothesis regarding the Swan Label's impact on resource efficiency

\begin{tabular}{ll}
\hline Hypothesis & Causal relationship \\
\hline $\begin{array}{l}\text { Resource efficiency } \\
\text { The Swan Label reduces companies' } \\
\text { production costs }\end{array}$ & $\begin{array}{l}\text { More effective use of resources, e.g. less usage of water, energy } \\
\text { and less waste disposal }\end{array}$ \\
& $\begin{array}{l}\text { Focus on long term benefits of changing or adjusting the production } \\
\text { Spill-overs from efficiency improvements towards other products } \\
\text { than the Swan labelled }\end{array}$ \\
& $\begin{array}{l}\text { Optimisation of the value chain through a focus on quality and } \\
\text { environmental demands }\end{array}$ \\
\end{tabular}

Source: DAMVAD, 2013.

\subsubsection{The Swan Label has a significant impact on resource efficiency}

Many of the interviewed companies describe that the Swan registration process has had impacts on the acquisition and use of resources. However, the magnitude and type of resources differs. In general, a separation can be made between the companies which have licensed their entire service or production facility (or licensed several products) and companies having only one or a few products licensed.

Companies from the first group have to meet strict requirements with regards to energy, water and waste, requiring that they need to document and measure consumption. Most companies start the process of registration by measuring their usage of these resources making it possible to document the effects after the Swan Label has been implemented. These companies experience significant changes due to the focus on resources which the Swan Label gives them. One example is Holmenkollen Rica Hotel in Norway (see more in the box and in the case description of the hotel below) which has been able to reduce its consumption of water by 40 per cent, power by 20 per cent and waste by 14 per cent from 2007 to 2012, despite the fact that the hotel has increased its capacity by 50 per cent. The effects of the measures taken have been larger than first anticipated and motivated to do the same in other of the group's hotels. 


\section{Saving resources with the Swan Label}

Many of the interviewed companies experience a significant impact on their use of resources when they implement the Swan Label in the company. For particular the service companies these savings can be seen in the form of a reduction in the use of electricity, heating and water usage. One company reports how they save 14 per cent on electricity yearly and EUR 10,000 on water usage. Others have very recently implemented the Swan Label but already within the first year see significant changes. Furthermore, waste management and sorting of waste is an area where the service companies see impacts.

While Rica Hotel in Norway has experienced a 14 per cent reduction in waste since the Swan Label's implementation from 2007-2012 (despite an increase of 50 per cent in capacity), Grand Hotel in Iceland has managed to reduce its waste down to 37 per cent of what it previously was. Vester Kopi in Denmark describes how they managed to reduce the use of resources for ten consecutive years - the Swan Label playing an important role in this along with other initiatives.

Companies with only Swan labelled products (and not a service or the entire company) are to a lesser degree able to measure the impact on resources after the introduction of the label. Firstly, the companies often cannot disaggregate the resource usage to each specific product and, secondly, many products are licensed as they enter the market and never produced as a none-labelled product. However, also among these companies reductions on resources can be seen. This happens when companies producing products which contains chemicals not allowed according to the Swan criteria are forced to replace these with more environmentally friendly alternatives. Some companies find that they can leave out the chemicals from their products without replacing them, resulting in a cost reduction for the production of the product. Other companies must replace the chemicals with other substances, which in some instances lead to an increase in costs for producing the product while in other cases it leads to cost reductions. As described above, another result will often be improvements in work well-being. Examples of this from two printing companies can be seen below. 


\section{Changes in production costs}

As presented earlier, some companies have experienced that the registration of the Swan Label led to an increase in production costs. However, many companies, regardless of whether they are service or production companies, also experienced reductions in production costs. Some companies manage to change the composition of inputs to their products or services making them less costly to produce. Vester Kopi, a printing company in Denmark changed its paper to a more environmentally friendly version following the criteria process of the Swan Label and managed to save 3-5 per cent on their yearly expenses on paper. Oddi, a printing company in Iceland, changed its washing agents used in the production and as a side effect experienced that their printing rolls now lasts 3-4 months longer then before. These companies also changed other materials resulting in cost reductions and stopped using certain inputs in their production processes resulting in a less costly production.

At other times companies experience rising production costs. This happens because the more environmentally friendly inputs to the production tend to be more expensive.

All in all, the Swan Label has a significant impact on the use of resources for most of the companies. This impact has during the interviews especially been seen for waste handling and disposal, the use of electricity as well as the use of water. As with the other impacts the magnitude and volume differs across companies depending on e.g. whether the company has past experience with reductions in resources or if the company has other initiatives, such as environmental standards, implemented. 


\title{
Case: Holmenkollen Park Hotel Rica Oslo - Norway
}

\author{
Motivation \\ Holmenkollen Park Hotel Rica was the first Rica hotel in \\ Norway to meet the requirements of the Swan Label \\ when it registered in 2008 \\ Holmenkollen Park Hotel Rica decided to become Swan \\ Labelled because of an increased environmental \\ awareness both from private customers and professional \\ players such as conference organisers and public
}

About Holmenkollen Park Hotel Rica authorities. The motivation was primarily based on the

Holmenkollen Park Hotel Rica is one out of nearly 80 RICA hotels in Norway and Sweden. The hotel was Swan labelled in 2008 (45 RICA hotels were Swan labelled in 2012)

Employees: About 200 at Holmenkollen Park Hotel Rica (about 3500 for all hotels) Location: Oslo, Norway

Capacity: The hotel has 336 rooms (capacity increase of 5000 square meters / 115 new rooms in 2011).

expectation of increased sales and customer confidence, however, it was also expected that the process of registration would bring a better overview and savings in electricity and water usage. The rationale for choosing the Swan Label was that the Swan Label is tougher and more robust than other eco labels.

Implementation

The manager of the hotel took the initiative to start the registration process and formed a group responsible for the implementation consisting of employees from the technical department, the sales and marketing department, housekeeping and the kitchen. The license was granted about 6 months after the hotel started the implementation process.

During this period, they undertook a thorough documentation and measurement of resource usage before making the necessary adjustments and investments. The hotel did some initial direct investment in new equipment such as filters for showers and waste management facilities. The hotel also implemented a number of water and energy saving measures such as using more energy efficient light bulbs, reducing the use of outdoor lighting, reducing the water temperature, reducing the water consumption in showers and toilets, and installing light sensors to reduce the lighting in areas not constantly in use.

Impact

The hotel is using the label to easily communicate its environmental awareness in marketing material. The label also simplifies documentation of the hotel's environmental work in public tenders. The largest impacts are related to resource savings, which again reduce the operating costs of the hotel. This impact is larger than initially anticipated and the investments had a payback-period of only 2-3 years. The consumption of water is down about 40 per cent since 2007 and power consumption is down about 20 pe cent by using water saving systems for showers and toilets. The amount of waste is down about 14 per cent since 2007, and the cost of waste disposal has been reduced by 50 per cent. In addition, the hotel reduced its consumption of chemicals such as chlorine but this saving is not easily measureable as consumption varies from year to year. Furthermore, the hotel has introduced more local and organic food as part of the hotel's services.

\subsubsection{The Swan Label's impact on suppliers and subcontractors}

Many companies describe that they had to change or replace some input factors or suppliers; however, they do not always see this as a result of the Swan Label. In general three different types of arguments/companies are seen: 
- The companies that recognise that the process of acquiring the Swan Label led to changes in input factors.

- The companies that recognise that the process of acquiring the Swan Label led to changes in input factors, but would have made these changes anyway due to regulations or other external influences.

- The companies that argue that the they have not had changes in the use of resources.

Still, most companies describe that they to some extent have had to change suppliers or input materials during the Swan registration process and that the documentation requirement to some extent have affected their procurement practise and dialogue with suppliers. Some even argue that they have been able to change the products and/or product wrapping from suppliers so to reduce waste. An example of this can be seen in the box below.

\section{Applying pressure on subcontractors}

Traditionally, hotel restaurants have used butter in portion sized packages resulting in a significant amount of waste. The Rica Hotel chain "joined forces" with other hotels and applied pressure towards their main supplier of butter to get rid of the wrapping. The supplier made changes affecting both production and transport, and today, many hotels in Norway gets butter delivered in single portion units - frozen without any wrapping.

In order to document the production of input factors the Swan labelled companies need to collect documentation from their suppliers. In most cases the suppliers are able to provide sufficient documentation but it is not uncommon that the suppliers are not able to provide sufficient documentation. In such a case, a company often has to change its supplier.

However, the fact that a company has changed it suppliers does not need to imply that the previous supplier did not act according to the Swan criteria, but that they were not able to come up with the necessary documentation. The production of textiles is an input factor for which some of the interviewed companies have experienced difficulties in getting sufficient documentation (e.g. water quality in the area of the production and colouring facilities).

The consequences of such changes are not always the same. Some companies find suppliers which are less costly and actually experience a decrease in costs. Others find the Swan criteria limiting for the company's 
choices as the tightened demands for inputs to their products means that they have less suppliers to choose from. This often leads to higher costs.

\subsection{The impact on innovation and development}

Regarding innovation and development it is hypothesised that having the Swan Label will lead to investments in product development and optimisation of production processes - in the form of new innovative approaches to such processes. It is also expected, that companies living up to the Swan criteria will gain knowledge on how an environmentally friendly product is produced, thereby improving product development.

The interviews show, however, that it is difficult for companies to actually pinpoint to the innovation resulting from the Swan Label. Companies constantly have to be innovative both in terms of products, organisation and production processes in order to stay competitive. This innovation comes from concrete measures taken internally but is also affected by factors outside of the company. Consumers, competitors, regulation and other factors affect the market in which they operate and the innovations they develop. However, a number of interesting impacts of the Swan Label has been found.

Table 9: Hypothesis regarding the Swan Label's impact on innovation and development

\begin{tabular}{ll}
\hline Hypothesis & Causal relationship \\
\hline $\begin{array}{l}\text { Innovation and development } \\
\text { phe Swan Label provides motivation for development and innovation }\end{array}$ & $\begin{array}{l}\text { The changes and developments of the Swan criteria lead } \\
\text { companies to invest more in product development and } \\
\text { optimisations in the production }\end{array}$ \\
& $\begin{array}{l}\text { Companies gain access to new and updated knowledge on } \\
\text { product development via the Swan labelling process }\end{array}$ \\
Companies foresee and reduce costs incurring from envi- \\
ronmental regulation
\end{tabular}

Source: DAMVAD, 2013.

\subsubsection{The Swan Label forces new developments upon the companies}

The product companies acquiring the Swan Label for their products basically consist of two types: companies having a product which they want to be more environmental friendly and companies wishing to get a "stamp of approval" on an existing environmentally friendly product, as described earlier. 
The first type of company is often "forced" to develop on the product in order to make it environmentally friendly. Often, companies must change the input materials for their products to be able to have them accepted under the Swan Label. This e.g. happens when a company has to substitute a chemical in a certain product or change a specific material from a non-degradable to a degradable. These companies product develop as a reaction to the Swan criteria. As explained above, these changes can lead to higher or lower costs. Undri, an Icelandic soap producer is an example of this.

\footnotetext{
Product development as a reaction to the Swan Label

Undri, an Icelandic soap producer, decided to become Swan labelled in $2000 / 2001$. As part of the process and due to the Swan criteria the company removed some substances from the soap and replaced others. The removal of substances led to direct savings for the company as it did not have to purchase these any more. The new substance they had to put in, however, was more expensive than the previously used substance making the production costs higher. Over time the price on this substance has reduced bringing the costs of the product down to the previous level.
}

The second type of company already has an environmentally friendly product and wishes to signal this to the customer (consumers, public organisations or other companies). These companies, contrary to the above, often do not have to make significant changes to their products. The products already fulfil the criteria a 100 per cent or close to and only documentation must be provided in order to obtain the Swan Label.

The service companies (hotels and printing companies) interviewed experience the Swan Label's impact on innovation in different ways. For hotels the impact of the Swan Label can mainly be seen in the reduction of resources and to a lesser degree in newer developments. However, some argue that they use the work undertaken as a part of the Swan to offer green or eco conferences, or increase the amount of organic or local food in their restaurants. See the case description of Grand Hotel Reykjavik below for an example of this.

The printing companies are largely affected by technological changes in their industry. The change towards digital printing makes the printing industry more environmentally friendly and the Swan Label cannot be credited for this development. However, having the Swan Label makes the companies able to offer new services - e.g. printing on "green" paper or offering Swan labelled brochures, posters etc. 
Some companies experience that the Swan Label has led to changes in the development of new products and services by subcontractors. This happens because the now Swan labelled companies put pressure on the value chain (as described above) and "force" their subcontractors to deliver according to the demands of the Swan criteria. If these subcontractors wish to continue their business with the Swan labelled company they are often obliged to perform some changes to their products or services. 


\section{Case: Grand Hotel Reykjavik - Iceland}

\section{Motivation}

The Grand Hotel Reykjavik decided to become Swan Labelled because of an increased environmental awareness among their customers and in society in general. The hotel wanted to be a first-mover by having the Swan Label but has been having a focus on the environment for many years.

About Grand Hotel Reykjavik
Grand Hotel Reykjavik is the largest hotel in
Iceland having 312 rooms. The Hotel acquired
its Swan Label in March of 2012.
Employees: App. 150
Location: Reykjavik, Iceland

The hotel also registered some demand from customers

particularly for environmentally friendly conferences and as a whole expected to gain increased sales from having the Swan Label. Furthermore, it was expected that the hotel could get a better overview and an increased focus on the cost and usage of resources such as water, electricity, waste, etc.

\section{Implementation}

The implementation of the Swan Label at the Grand Hotel was organised through a committee of four employees from the management of the hotel and with the assistance of a consultant. These went through the changes necessary and the data needed to be supplied for the Environmental agency and organised the process. Over a time frame of 6-7 months the changes needed were implemented. This included a number of changes, some minor some major, including e.g. a more thorough approach to waste sorting, changing all light bulbs to energy saving light bulbs, changes in washing procedures of linens and towels, etc.

\section{Impact}

The Grand Hotel has experienced a number of effects stemming from the Swan Label. First of all, the hotel is now able to signal its environmental awareness by using the Swan Label on communication material and by having the logo on posters, flags, etc. Most effects, however, are internal and come in the form of savings on resources. The hotel has, thus, experienced savings in the costs of waste disposal due to increased sorting of the waste, reductions in electricity use, since the stop of using bleach in the cleaning process saved the price of 1,5 tons of bleach every year, etc.

Furthermore, the hotel has now introduced a new service - green meetings/conferences - and introduced an organic breakfast buffet as part of the hotel's services.

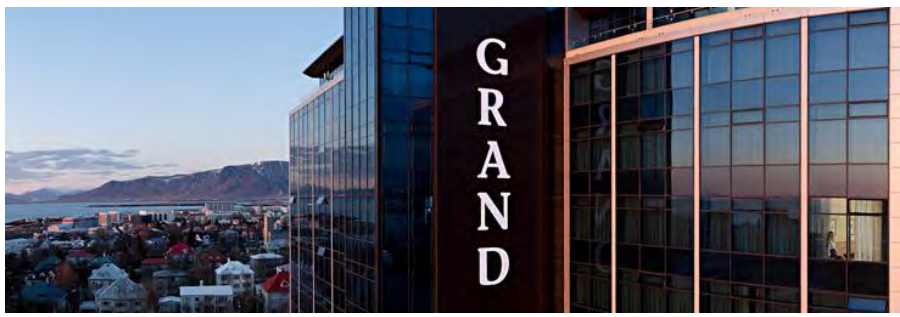




\subsubsection{Access to knowledge brings spill-over effects towards other products}

The interviews have shown that the Swan labelling process has the potential to bring changes to the production of goods and services that are not labelled. For some companies, these spill-over-effects are relatively easy to identify but for others the changes become such an integrated part of the production and operation that it is not possible to identify where the spill-over effects have occurred. Furthermore, it is often not possible to justify that the Swan Label is the sole responsible factor for these effects.

For production companies, this can be seen when input factors in the production of Swan labelled products are also implemented in the production of other products. Jensen (a producer of beds) replaced some of the textiles of their Swan labelled products as a part of the Swan registration process, which they now use both in the production of labelled and non-labelled products. Producers of detergents and paint report similar experiences.

Service companies also find that the measures taken to reduce the use of resources have given them some valuable experiences affecting for instance other hotels in the chain. Rica Holmenkollen Hotel in Oslo has served as a pilot case for the entire Rica chain which resulted in the implementation of resource saving measures in several other hotels. More than 40 Rica hotels have since then been licensed. However, a few of the older hotels in the chain do not satisfy the criteria of the swan but have still implemented measures to reduce resource usage (and costs).

\subsubsection{Being at the forefront of environmental regulation}

Several of the companies interviewed argue that they continuously strive to be in the forefront of environmental regulation. The Swan Label is often used by these companies as a way of implementing stricter environmental demands into their production processes or other internal processes. The companies do this because they expect environmental regulation to be tightened in the near future and want to be prepared for such changes.

One company describes how having the Swan Label "keeps us on our toes" and makes sure that the company has a determined focus on the environmental impact of their activities. 


\subsubsection{Using the Swan Label as a tool for internal change}

As described in chapter 5 the motivation for some companies for acquiring the Swan Label stems from a wish to streamline internal processes in the company.

Many of the interviewed companies describe how this is not only a motivation for acquiring the Swan Label but also an impact which actually occurs. The companies will often have an employee or a group of employees in charge of implementing the consequences following from the Swan criteria. While these are focused on implementing the necessary changes for the company to be able to have the Swan Label, some companies also use the occasion to streamline their processes or work routines. This e.g. happens when some companies, while implementing the changes necessary, choose to also put a focus on safety measures in the production. Icelandic company Oddi is an example of this.

\section{Improvements in safety}

As part of the process of implementing the Swan Label, Oddi changed and improved its safety procedures in the production. Among other things, safety equipment was installed in central places and is now available at strategic locations around the facility. As part of the process Oddi decided to train and update its production staff in safety procedures. Now, an annual course is given to keep employees up-to-date with safety requirements.

As such, the Swan Label can be said to be the driver of companies' work on reducing their environmental footprint but also of efficiency improvements with regards to production processes in general.

\subsection{Impact of the Swan Label - an overview}

As described above, the impact following from the Swan Label differs according to a number of factors as well as it differs in number and volume. As such, it is not possible to derive an exact number or quantification of the impact of the Swan Label which can be said to be true for all companies across sizes, sectors, countries, experience with environmental initiatives, etc.

However, the following table summarises the impact found across all companies and includes a number of quantitative, qualitative and concrete examples of impact which the interviewed companies have experienced. This does not imply that a company will be able to experience the 
same impact if it implements the Swan Label - it is examples and cannot be generalised to all companies - but it gives an overview of the possible benefits a company can achieve.

\section{Table 10: Overview of the impact of the Swan Label experienced by the companies}

\begin{tabular}{|c|c|}
\hline Impact & Examples observed \\
\hline \multicolumn{2}{|l|}{ Marketing and branding } \\
\hline \multirow[t]{2}{*}{$\begin{array}{l}\text { New customers/ } \\
\text { Higher sales }\end{array}$} & $\begin{array}{l}\text { Being able to sell to certain new customers demanding Swan labelled prod- } \\
\text { ucts/services }\end{array}$ \\
\hline & One company gained 2 new customers by having the Swan Label \\
\hline Better profiling/branding & $\begin{array}{l}\text { All companies interviewed find that the Swan Label improves their branding } \\
\text { and/or profile in the market }\end{array}$ \\
\hline \multicolumn{2}{|l|}{ HR and recruitment } \\
\hline $\begin{array}{l}\text { Improved motivation of } \\
\text { employees }\end{array}$ & Employees involved in implementation process feel motivated \\
\hline \multirow{2}{*}{$\begin{array}{l}\text { Increased attractiveness } \\
\text { as a work place }\end{array}$} & The Swan Label is a part of "the package" which a company offers \\
\hline & Employees feel they contribute to a better world \\
\hline \multirow[t]{3}{*}{ Improved work well-being } & A decrease in the use of chemicals led to higher safety \\
\hline & A decrease in chemicals led to less odour in the production \\
\hline & A decrease in the likelihood of accidents due to improved routines \\
\hline \multirow[t]{2}{*}{$\begin{array}{l}\text { Courses and training for } \\
\text { employees }\end{array}$} & $\begin{array}{l}\text { Employees trained in the new routines stemming from the implementation of } \\
\text { the Swan Label }\end{array}$ \\
\hline & $\begin{array}{l}\text { Employees trained in other routines and processes while changing Swan Label } \\
\text { influenced routines }\end{array}$ \\
\hline \multicolumn{2}{|l|}{ Resources } \\
\hline \multirow{10}{*}{$\begin{array}{l}\text { More effective use of } \\
\text { resources, e.g. less usage } \\
\text { of water, energy and less } \\
\text { waste disposal }\end{array}$} & Savings of 14 per cent on electricity per year \\
\hline & Savings of EUR 10,000 on electricity annually \\
\hline & Decrease in the use of resources for many consecutive years \\
\hline & $\begin{array}{l}\text { Changing all light bulbs in hotel to energy savings light bulbs resulting in a } \\
\text { decrease in electricity use }\end{array}$ \\
\hline & Increased focus on the use of heating led to reduced expenditures \\
\hline & Increased focus on the use of water led to reduced expenditures \\
\hline & Waste disposal improvements leading to lower costs \\
\hline & None-recyclable waste reduced to 37 per cent of previous use \\
\hline & $\begin{array}{l}\text { None-recyclable waste reduced to nearly } 0 \text { per cent for one company compared } \\
\text { to previous use }\end{array}$ \\
\hline & $\begin{array}{l}\text { None-recyclable waste reduced by } 14 \text { per cent for another company compared } \\
\text { to previous use }\end{array}$ \\
\hline \multirow{4}{*}{$\begin{array}{l}\text { Long term benefits of } \\
\text { changing or adjusting the } \\
\text { production }\end{array}$} & $\begin{array}{l}\text { Longer life-time of materials/technology used in the production due to new } \\
\text { routines/input material }\end{array}$ \\
\hline & Savings in the use of input material because they are dropped/removed \\
\hline & Savings in the use of input material because they are cheaper to use \\
\hline & Savings in the use of input materials because less needs to be used \\
\hline \multirow{2}{*}{$\begin{array}{l}\text { Spill-overs from efficiency } \\
\text { improvements towards } \\
\text { other products than the } \\
\text { Swan labelled }\end{array}$} & $\begin{array}{l}\text { The Swan Label acts as a driver for focusing on savings everywhere in the } \\
\text { production }\end{array}$ \\
\hline & $\begin{array}{l}\text { Changes to Swan labelled products and services can have positive effects for } \\
\text { non-labelled products and services }\end{array}$ \\
\hline \multirow{2}{*}{$\begin{array}{l}\text { Optimisation of the value } \\
\text { chain through a focus on } \\
\text { quality and environmen- } \\
\text { tal demands }\end{array}$} & Subcontractors forced to change products \\
\hline & $\begin{array}{l}\text { Pressure from Swan labelled company led to reduced use of packaging at } \\
\text { subcontractor }\end{array}$ \\
\hline
\end{tabular}


Innovation and development

The changes and developments of the Swan

criteria lead companies to

invest more in product

savings in production costs as seen above

development and optimi-

sations in the production

Hotel develops organic breakfast service

Hotels offer green meetings and conferences

Savings in the use of input material because they are dropped/removed

Savings in the use of input material because they are cheaper to use

Savings in the use of input materials because less needs to be used

Decrease in the use of a chemical for a printing company from 20,000 litres per year down to 13,000 litres

Change of paper led to $3-5$ per cent decrease in expenditure yearly for printing company

The use of chlorine for washing towels and linens in hotel stopped resulting in savings in expenses for 1.5 tonnes each year

The use of shampoos, etc. in hotel rooms stopped resulting in savings

Change of plastic glasses in hotel room with "real" glass - savings on materials

Companies gain access to new and updated

The Swan Label is a driver for changes and development for some companies The Swan Label acts as a driver for focusing on savings everywhere in the

knowledge on product

development via the production

Input materials used in Swan labelled products are also used in production of non-labelled products

Experience made in one hotel have brought changes to other parts of the hotel chain

Companies foresee and reduce costs incurring

Companies implement the Swan Label to be ahead of coming environmental

from environmental regulation

Source: DAMVAD, 2013 


\section{Appendix: List of references}

\section{Basic information regarding the Swan Label retrieved at:}

Nordic ecolabelling: www.nordic-ecolabel.org/about/

Ecolabelling Denmark: www.ecolabel.dk/svanenblomsten/omsvanenblomsten/

Ecolabelling Finland: http://www.ymparistomerkki.fi/english

Ecolabelling Iceland: http://www.ust.is/einstaklingar/umhverfismerki/svanurinn/

Ecolabelling Norway: http://www.svanemerket.no/

Ecolabelling Sweden: http://www.svanen.se/en/

\section{Reports and other references:}

The coexistence of two Ecolabels - The Nordic Ecolabel and the EU Ecolabel in the Nordic Countries, DAMVAD 2013, forthcoming.

DAMVAD (2013): "Standarder som værdiskaber i danske virksomheder”, Erhvervsstyrelsen. 



\section{Sammenfatning}

\section{Introduktion og konklusioner}

Nordisk Ministerråd har bedt DAMVAD (se damvad.com) om at udføre en analyse af effekterne af det nordiske miljømærke - Svanemærket. Formålet med analysen er, at undersøge de betydninger det kan have for en virksomhed at erhverve sig Svanemærket, uanset om virksomheden har et enkelt godkendt svanemærket produkt, eller om hele virksomheden er svanemærket.

Analysen tager imidlertid et bredt fokus, og undersøger de følgende tre temaer:

- Virksomhedernes motivation for at erhverve sig Svanemærket.

- Implementeringen af Svanemærket.

- Effekten af at erhverve sig Svanemærket.

Den centrale del af analysen er identifikationen af de effekter, som Svanemærket kan føre til. For at kunne forstå og reflektere over effekterne, er det dog vigtigt at forstå de motivationsskabende faktorer der ligger til grund for, hvorfor virksomhederne erhverver sig Svanemærket, og hvordan de implementerer mærket.

\section{Analysens konklusioner}

Analysen, som er foretaget blandt 16 virksomheder i de fem Nordiske lande, har gjort det muligt at identificere et antal konkrete eksempler på omkostninger og fordele, som Svanemærket har haft for virksomheder i forskellige dele af værdikæden.

Alle de interviewede virksomheder oplevede en effekt fra Svanemærket, men hvilken type og størrelsesordnen af effekten varierer i høj grad. Udvælgelsen af de virksomheder, som er interviewet i analysen, er gjort med overvejelser om at afdække alle de fem nordiske lande, flere og forskellige sektorer (som for eksempel hoteller, printervirksomheder, produktionsvirksomheder og møbelproducenter) såvel som forskellige virksomhedsstørrelser. 
De dele af analysens konklusioner, der dækker virksomhedernes motivationsskabende faktorer, hvordan de implementerer Svanemærket samt effekterne af Svanemærket, er beskrevet i det følgende. Disse tre temaer er behandlet hver for sig i analysen, og konklusionerne for hvert tema er præsenteret.

\section{De primære motivationsskabende faktorer for at erhverve sig Svanemærket er at opretholde/anskaffe sig en grøn profil og at øge salget}

Analysen har identificeret en række motivationsskabende faktorer ved at erhverve sig Svanemærket. De to dominerende faktorer - omtalt af alle virksomhederne - er, at virksomhederne ønsker at opretholde eller anskaffe en grøn virksomhedsprofil, samt at de ønsker at øge salget.

Den første gruppe af virksomheder er enten virksomheder, der har haft en grøn profil i årevis, og som ønsker at forstærke denne yderligere, eller virksomheder der ønsker at anskaffe sig en grøn(nere) profil ved at bruge Svanemærket som et "godkendelsesstempel" af deres miljømæssige indsats.

Alle interviewede virksomheder har ydermere et ønske om at øge deres salg gennem implementeringen af Svanemærket. De implementerer Svanemærket med det håb, at brandingværdien af mærket vil hjælpe med at øge salget enten fra eksisterende kunder eller nye kunder. Mange af virksomhederne har set en stigende interesse blandt kunder, som er forbrugere, andre virksomheder eller den offentlige sektor, for at købe grønne produkter eller services. Som svar på dette erhverver virksomhederne sig Svanemærket. Et eksempel på dette er den finske producent af hygiejne produkter Delipap Oy, som blev motiveret direkte af én af virksomhedens større kunder - en private label virksomhed, som ville have Svanemærket på deres produkter.

Andre motivationsskabende faktorer spiller imidlertid også en rolle, når virksomheder vælger at erhverve sig Svanemærket. For nogle virksomheder er der et markedspres for at anskaffe sig Svanemærket. I nogle sektorer er Svanemærket blevet en markedsstandard, som gør det umuligt at sælge produkter eller servicer uden at have Svanemærket. Andre virksomheder oplever et pres fra forbrugerne eller samarbejdspartnerne.

For andre virksomheder er motivationen for at implementere Svanemærket en ambition om at være på forkant med kommende miljøreguleringer eller om at effektivisere produktionen ved at bruge Svanemærket som drivkraft. 


\section{Svanemærket styrker den miljømæssige profil og kan være en forudsætning for salget}

Svanemærket har en positiv påvirkning på virksomhedens salg og markedsføring, da det gør det nemt at kommunikere og markedsføre det miljømæssige arbejde som virksomheden laver. En virksomhed beskriver Svanemærket som "et signal til forbrugeren om at vi sætter handling bag vores ord." Adskillige virksomheder beskriver hvordan Svanemærket har forbedret deres miljøprofil og givet dem bedre eksponering over for deres kunder. Svanemærket forbedrer markedsføringsmulighederne og signalere kvalitet og ansvar.

På nogle markeder er Svanemærket blevet en forudsætning for at sælge produkter eller services - dvs. en markedsstandard - og virksomhederne understreger, at de ikke ville være aktive på markedet uden Svanemærket. Et eksempel på dette er DUNI, en svensk producent af servietter og lys. Der er en markedsefterspørgsel fra hotel og restaurant markedet, som er baseret på at produkterne skal være Svanemærket - at have Svanemærket er blevet en markedsstandard og en forudsætning for at sælge for DUNI.

De interviewede virksomheder forklarer dog også, hvordan Svanemærket er "en del af den pakke," som virksomhederne sælger og en af flere konkurrenceparametre sammen med pris, kvalitet, image, osv.

\section{Svanemærket forbedrer arbejdsmiljøet og gør medarbejderne stolte}

For nogle af de interviewede virksomheder har Svanemærket haft en positiv effekt på arbejdsmiljøet. Dette sker, når virksomhederne pga. Svanemærke kriterierne, er "tvunget" til at udskifte kemikalier eller andre stoffer i deres produkter. Dette mindsker ofte risikoen for arbejdsuheld, og kan gøre produktionen mere komfortabel at arbejde med, når eksempelvis stærke lugte bliver fjernet fra produktionen. Undri, en islandsk sæbeproducent, fjernede et kemikalie fra et af deres produkter som følge af Svanemærkeprocessen. Dette førte til et bedre arbejdsmiljø, da produktionsområdet ikke længere havde lugten fra det tidligere brugte kemikalie.

Svanemærkets effekt på rekruttering er mindre klar. Virksomhederne hævder, at Svanemærket er en relevant faktor ved jobvalg (i særdeleshed når der arbejdes i industrier, hvor fysisk arbejdsmiljø er vigtigt), men andre faktorer som løn, beliggenhed, aktivitet, management, jobsikkerhed, osv., spiller en vigtigere rolle. De fleste af de interviewede virksomheder hævder dog, at det er deres oplevelse, at virksomhedens overordnede miljøprofil er vigtig for medarbejderne, og Svanemærket 
spiller en væsentlig rolle for de fleste virksomheder i denne kontekst. Derfor, når det kommer til rekruttering såvel som at holde på medarbejdere, finder mange af de interviewede virksomheder at det at have Svanemærket og være miljømæssig ansvarlig, gør medarbejderne stolte af deres arbejdsplads.

\section{Svanemærket har en signifikant effekt på ressourceeffektiviteten}

Mange af de interviewede virksomheder beskriver, at Svanemærket har haft effekter på anskaffelsen og brugen af ressourcer. Størrelsesordnen og typen af ressourcer varierer dog. Generelt set, kan der laves en adskillelse mellem de virksomheder, som har licenseret hele deres service eller produktionsfacilitet (eller licenseret flere produkter) og virksomheder, som kun har et eller få licenserede svaneprodukter.

Virksomheder fra den første gruppe skal imødekomme strenge krav med hensyn til energi, vand og spild, og oplever signifikante ændringer på grund af det fokus på ressourcer som Svanemærket giver dem. Eksempler på effekter for den slags virksomheder er reduktioner i årligt spild på $14 \%$ og en besparelse på 10.000 EUR på brug af vand pr. år.

Virksomheder med kun svanemærkede produkter (og ikke service eller hele virksomheden) er i mindre grad i stand til at måle effekten på ressourcer efter introduktionen af mærket. Blandt disse virksomheder kan der dog også ses reduktioner på ressourcer. Dette sker, når virksomhederne producerer produkter, som indeholder kemikalier, der ikke er tilladt i henhold til Svanemærke kriterierne, og derfor bliver tvunget til at udskifte disse til mere miljøvenlige alternativer. Nogle virksomheder opdager, at de kan udelade disse kemikalier fra produktionen uden at udskifte dem, hvilket resulterer i en omkostningsreducering i produktionen af produktet. Andre virksomheder er nødt til at udskifte kemikalierne med andre stoffer, hvilket i nogle tilfælde fører til en stigning i omkostningerne i produktionen af produktet, mens det i andre tilfælde fører til omkostningsreduceringer.

Andre eksempler på besparelser på ressourcer er reduceringer i de brugte kemikalier for en printervirksomhed fra 20.000 liter pr. år til 13.000 liter, og et hotel som ikke længere bruger klorin når der vaskes håndklæder og sengetøj - en besparelse på 1,5 tons klorin pr. år. 


\section{Svanemærket tvinger virksomhederne til at udvikle sig}

Virksomheder der erhverver sig Svanemærket, er ofte "tvunget" til at udvikle på produktet for at gøre det miljøvenligt. Mange virksomheder er nødt til at ændre input materialerne ved produkterne for at kunne få dem accepteret under Svanemærket. Dette sker f.eks., når en virksomhed bliver nødt til at erstatte et kemikalie i et bestemt produkt eller ændre et specifikt materiale fra ikke-nedbrydeligt til nedbrydeligt. Disse virksomheder produktudvikler, som en reaktion på Svane kriterierne.

Servicevirksomheder oplever Svanemærkets effekt på innovation forskelligt. For hoteller kan effekten af Svanemærket hovedsagligt ses i reduktionen af ressourcer og i mindre grad i nyere udvikling. Nogle forklarer dog, at de bruger arbejdet der udføres som en del af Svanen til at tilbyde grønne- eller økokonferencer, eller til at øge omfanget af økologisk eller lokal mad i deres restauranter. Printervirksomheder er i høj grad påvirket af teknologiske ændringer i industrien. Ændringerne i retning mod digital printning gør printerindustrien mere miljøvenlig denne udvikling kan Svanemærket ikke tilskrives. Erhvervelsen af Svanemærket giver dog virksomhederne mulighed for at tilbyde nye services - f.eks. printning på "grønt" papir eller tilbyde svanemærkede brochurer, posters osv.

\section{Svanemærket fører til ændringer i produktionsomkostninger}

Virksomhederne, som implementerer Svanemærket, skal alle betale en række gebyrer for at kunne få lov til at bære mærket. Disse gebyrer er de direkte omkostninger ved at implementere Svanemærket, og består af et ansøgningsgebyr, et fornyelsesgebyr samt et årligt gebyr baseret på salget af de Svanemærkede produkter eller services.

De virksomheder, som implementerer Svanemærket, oplever dog også, at der er en række indirekte omkostninger forbundet med at have mærket. Mest iøjnefaldende er ændringerne i produktionsomkostningerne, som følger af Svanemærket. Virksomhederne oplever dette, når Svanemærket har kriterier, der "tvinger" dem til at ændre inputmateriale i produktionen eller til at investere i maskineri eller andet udstyr. Virksomhederne er ofte nødt til at ændre råmaterialer til andre alternativer, som er mere miljøvenlige, men også mere omkostningsfuldt. Derudover har flere virksomheder oplevet, at de har færre leverandører at vælge mellem, når de skal købe miljøvenlige materialer. Det skal dog bemærkes, at nogle virksomheder oplever, at de nye miljøvenlige materialer er billigere at købe, eller at de blot kan stoppe med at bruge nogle af materialerne og dermed spare omkostningerne på disse. Et eksempel 
på dette er Grand Hotel Reykjavik på Island, som ændrede en række af processerne på hotellet, og var nødsaget til at skifte nogle af produkterne ud mens andre produkter og services kunne droppes uden ombytninger. På nogle områder har hotellet nu færre leverandører at vælge mellem, hvilket har resulteret i færre valgmuligheder og i nogle tilfælde højere omkostninger.

Andre indirekte omkostninger ved Svanemærket er den tid der bruges på ansøgningsproceduren, prisen på konsulentbistand og uddannelse og træning af medarbejderne. De interviewede virksomheder fremhæver især tiden brugt på ansøgningsproceduren, som en indirekte omkostning af implementeringen af Svanemærket. Tiden bruges på tættere dialog med underleverandører og leverandører såvel som indsamling af information vedrørende produkter, input materialer eller ressourceanvendelse.

\section{Effekten af Svanemærket varierer på tværs af virksomheder og markeder}

Analysen viser, hvordan effekten af Svanemærket varierer i meget høj grad på tværs af virksomhedernes størrelser. Effekter, specielt relateret til omkostninger, er ofte større for større virksomheder med mange ansatte. Derudover varierer effekten afhængigt af hvor professionelt virksomheden arbejder og afhængigt af deres eksisterende miljøbevidsthed. Nogle af de interviewede virksomheder har været miljøbevidste flere år forud for erhvervelsen af Svanemærket, og har erhvervet sig Svanemærket primært som et godkendelsesstempel. Disse virksomheder har allerede taget en række skridt for at blive mere miljøvenlige, og Svanemærket fører i disse tilfælde ikke til signifikante ændringer.

På samme måde varierer effekten på tværs af de sektorer, virksomhederne opererer på, samt udviklingen af sektorerne når det kommer til Svanemærket (er Svanemærket en standard på markedet eller noget nyt?). Nogle virksomheder opererer således på markeder, hvor Svanemærket allerede er en standard, hvilket betyder at den konkurrencemæssige fordel ved at erhverve sig Svanemærket er mindre end for foregangsvirksomheder på markeder, hvor Svanemærket endnu ikke er en forudsætning for at sælge varer eller services. For mange virksomheder er Svanemærket en forudsætning for at blive på markedet. 


\section{Effekten af Svanemærket er større for servicevirksomheder end for produktionsvirksomheder}

Baseret på de gennemførte interviews observeres det, at de ændringer der følger fra Svanemærket, er signifikant større for servicevirksomhederne end for produktionsvirksomhederne. Dette resultat kommer af, at for servicevirksomheder er hele virksomheden svanemærket, mens produktionsvirksomheder ofte blot svanemærker nogle af deres produkter.

For servicevirksomheder betyder dette, at de skal gå igennem mange af virksomhedens rutiner og processer, såvel som at de er nødsaget til at have et skarpt fokus på deres ressourceanvendelse. En produktionsvirksomhed der svanemærker et eller flere produkter, skal "kun" dokumentere materialerne og inputtene til disse produkter. Analysen viser, at der er flere "lavthængende frugter" at høste for servicevirksomhederne. Et eksempel på en sådan servicevirksomhed er Holmenkollen Hotel RICA i Oslo. Under licensproceduren har hotellet ændret rutiner og processer på hele hotellet og f.eks. skiftet alle elpærer, installeret vandbesparelsesudstyr og ændret dets håndtering af affald.

Derudover kan denne forskel i effekterne skyldes en holdningsændring i servicevirksomhederne i retning mod at blive mere miljøvenlig, mens denne trend i lang tid har været tydelig blandt mange produktionsvirksomheder. Endeligt spiller den tilskyndende struktur en vigtig rolle. Mens servicevirksomheder kan se en direkte og indirekte effekt på deres omkostninger, kan produktionsvirksomheder måske have svære ved at begrunde, hvorfor de skal ændre et input materiale til et andet dyrere materiale for at opnå et bedre image blandt kunderne.

\section{Succesfuld implementering af Svanemærket kræver engagement fra medarbejdere og ledelse}

For at en virksomhed skal opnå en succesfuld implementering af Svanemærket, er det nødvendigt at have engagement fra medarbejderne såvel som fra virksomhedens ledelse. Ledelsen har en vigtig rolle i at kommunikere fordelen ved Svanemærket ud til alle niveauer i virksomheden og til alle involverede medarbejdere. Forandringsledelse er et vigtigt koncept i denne sammenhæng. Det er vigtigt at involvere medarbejderne i implementeringsprocessen, da ændringerne i rutinerne og processerne direkte påvirker det daglige arbejde. Når disse ændringer forekommer, oplever nogle virksomheder frustration og negative reaktioner blandt medarbejderne. For at undgå den slags reaktioner er involveringen af personalet nøglen til succes. 


\section{Eksakt information om omkostninger og gevinster er begrænset}

De foretagne interviews har vist at det er svært at fremskaffe præcise estimater for værdien af Svanemærket for virksomhederne. Der er en række årsager til dette, herunder:

- Virksomhederne overvåger ikke de faktiske omkostninger og fordele ved Svanemærket.

- Nogle produkter og services bliver svanemærkede før de bliver sendt på markedet, hvilket betyder at det ikke er muligt at måle "før og efter" effecter.

- Effekten varierer på tværs af virksomhedsstørrelser og sektorer, hvilket gør det vanskeligt at estimere en eksakt værdi.

Disse pointer understreger udfordringen med at estimere og kvantificere en præcis værdi af Svanemærket der kan siges at gælde for alle virksomheder. Rapporten giver dog en række eksempler på de gevinster og omkostninger der kan opstå som følge af Svanemærket. Den overordnede opfattelse af Svanemærket blandt de interviewede virksomheder er positiv og som ovenfor nævnt bliver Svanemærket en integreret og vigtig del af virksomhederne.

For fremtidige analyser ser DAMVAD to primære muligheder for at skaffe mere viden om effekterne af Svanemærket. For det første har denne analyse vist, at servicevirksomhederne indrapporterer deres ressourceforbrug af vand og elektricitet m.v. til Svanemærkesekretariaterne. Det ville være interessant at se nærmere på dette data og analysere de ændringer i ressourceforbruget, som følger af kravene i Svanemærkningen.

For det andet ville det være interessant at udføre en "statistisk" effektmåling af de nordiske svanemærkede virksomheders performance, målt på f.eks. omsætning, eksport, beskæftigelse og produktivitet. Detaljeringsniveauet i data fra statistikbureauerne i de nordiske lande gør det muligt at sammenholde de svanemærkede virksomheder med en kontrolgruppe af virksomheder der ligner disse, men som ikke har svanemærkede produkter eller services. 


\section{norden}

Nordic Council of Ministers

Ved Stranden 18

DK-1061 Copenhagen K

www.norden.org

\section{The Nordic Swan and companies}

The purpose of the analysis is to study the implications it can have for a company to acquire the Swan License. The analysis takes a broad focus and investigates the following three themes:

- The motivation for companies to acquire the Swan Label

- The implementation of the Swan Label

- The impact of acquiring the Swan Label

The project aims at doing this by performing company visits to 16 companies from the five Nordic countries representing different company sizes and sectors.

The project is commissioned by the Swan group under the Working Group for Sustainable Consumption and Production (HKP gruppen) of the Nordic Council of Ministers. The analysis is conducted by DAMVAD with expert assistance from Åke Thidell, Lund University.

TemaNord 2014:523

ISBN 978-92-893-2758-9

ISBN978-92-893-2759-6 (EPUB)

ISSN 0908-6692

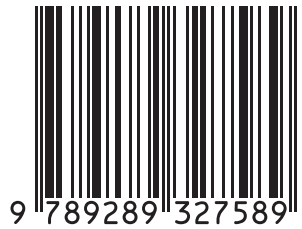

